Journal of Educational

and Psychological Sciences

Volume (5), Issue (39) : 30 Oct 2021

P: 1 - 22

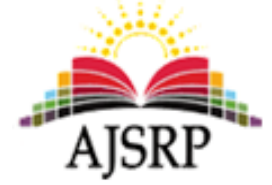

ISSN: 2522-3399

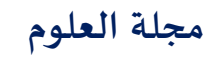

التربوية والنفسية

المجلد (5)، العدد (39) : 30 أكتوبر 2021 م

ص: 1 - n - n 12

\title{
The Role of School Administration in Developing Creativity and Its Obstacles as Perceived by School Principals in Government Schools in the Directorate of University District
}

\section{Sana Said Bdair}

Directorate of University District || Ministry of Education || Jordan

\begin{abstract}
This study aims at identifying the role of school administration in developing creativity and its obstacles as perceived by school principals in government schools in the directorate of University District. This may be attributed to variables of gender, academic qualification, years of experience, and school level. The researcher has used the descriptive analytical method through employing the use of a questionnaire. This questionnaire has been made of 36 sections. 28 sections were designed to identify the role of school administration in developing creativity in the government schools in the directorate of the university district, and 8 to identify the obstacles that face the school's administration. A sample of 55 male and female principals in government schools in the directorate of the university district have been chosen for the academic year 2019/2020. The results of the study showed that the application of creativity by the school principals in government schools have an overall average of (3.5 out of 5), which is rated as high. For the other two main areas, the administration one resulted with an average of (4.03) with a high rate, and for the obstacles area it resulted with (3.68) and was rated as large obstacles. It also has shown that there were no statistically significant differences in the role of school administration in developing creativity in government schools, which might be attributed to variables of academic qualification, years of experience, and school's level. However, there was a significant difference attributed to the gender variable, and it was in the favor of females. Based on those results, the researcher suggested a number of recommendations for developing creativity and limiting its obstacles at Jordanian Schools and other Arab countries.
\end{abstract}

Keywords: School administrations, government schools, directorate of university district, Jordan.

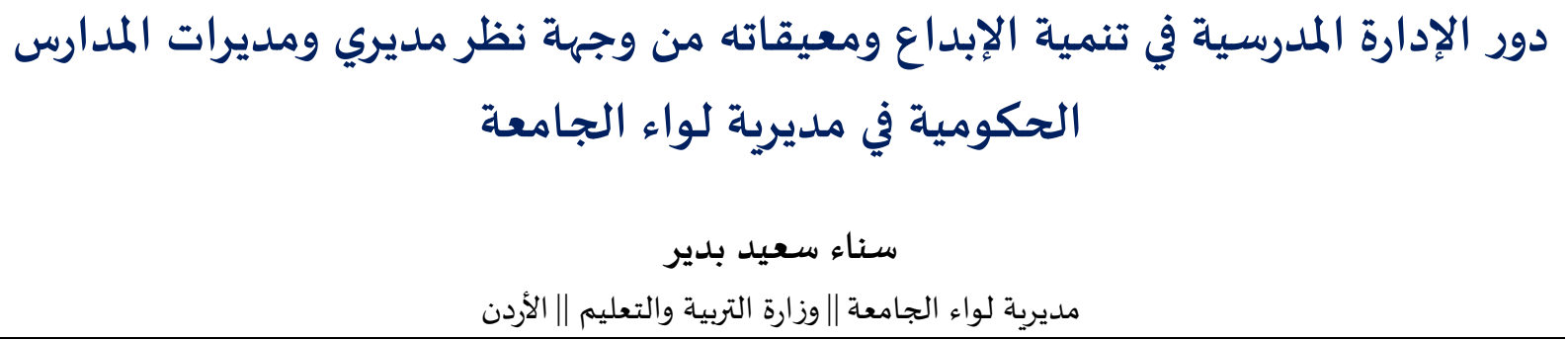

المستخلص: هدفت هذه الدراسة لمعرفة دور الإدارة المدرسية في تنمية الإبداع ومعيقاته من وجهة نظر مديري ومديرات المدارس الحكومية في مديرية لواء الجامعة باختلاف (الجنس، والمؤهل العلمي، وسنوات الخبرة، ومستوى المدرسة). استخدمت المداع الباحثة المنهج الوصفي التحليلي، وتم بناء استبانة تكونت من (28) فقرة للتعرف على درجة ممارسة الإدارة المدرسية لدورها في تنمية الإبداع في

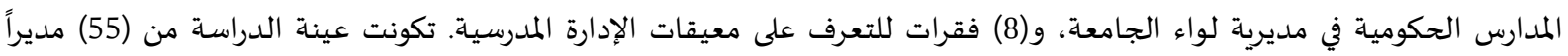
ومديرة في المدارس الحكومية في مديرية لواء الجامعة للعام الدراسي 2020/2019، أظهرت نتائج الدراسة أن درجة ممارسة الإدارة المدرسية لدورها في تنمية الإبداع حصل على متوسط كلي (3.86 من 5) أي بدرجة (مرتفعة)، وعلى مستوى المحورين الرئيسين :حصل 
محور دور الإدارة على متوسط (4.03) بتقدير (مرتفح)، وحصل محور المعيقات على متوسط (3.68) بتقدير (كبيرة)، كما أظهرت النّتائج

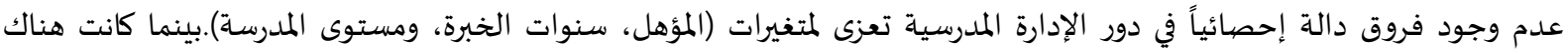

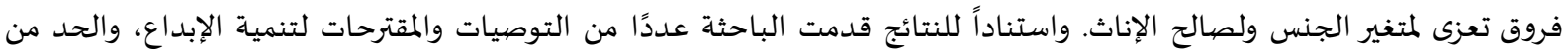
معيقاته في المدارس الأردنية وعموم البلدان العربية.

الكلمات المفتاحية: الإدارة المدرسية، الإبداع، المدارس الحكومية، لواء الجامعة. الأردن.

المقدّمة.

نتيجة للتطور والتقدم التكنولوجي والانفجار المعرفي، ومواكبة التغيرات التي تحدث في العالم. تسعى الدول للارتقاء بتعليم أبنائها في مختلف المراحل، حيث أصبح الإبداع سمة سائدة تسعى المؤسسات لتحقيقها، فهو الطريق لتحقيق الذات، وهو الذي يسهم في تطوير اتجاهات إيجابية نحو حلول المشكلات والتحديات التي تواجها الأفراد في

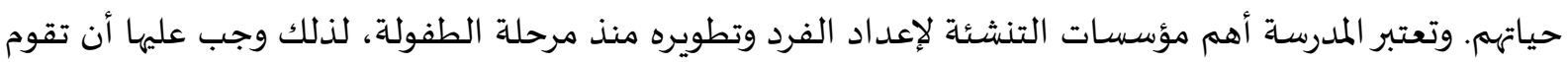
بتوظيف كافة إمكانياتها، ومواردها المختلفة لتشجيع الإبداع ورعايته، وتنميته لدى الماتهاتهات العاملين فيها.

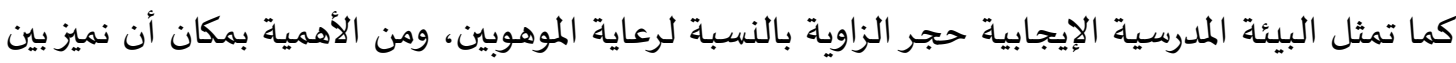

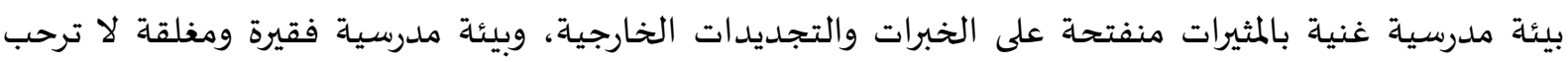

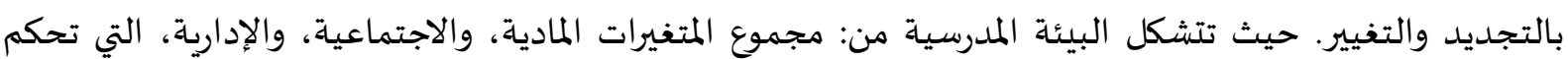

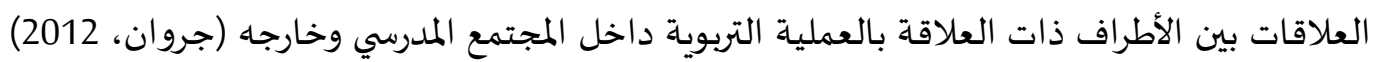

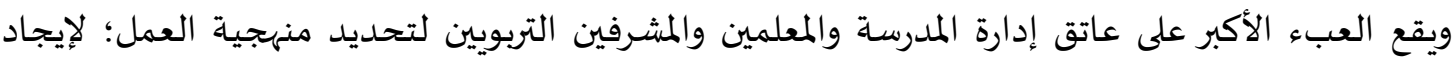

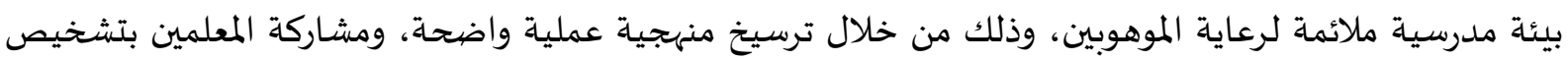

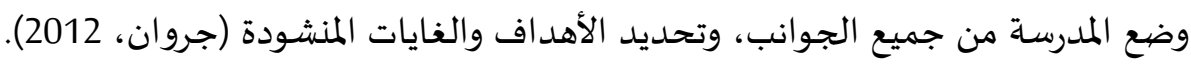

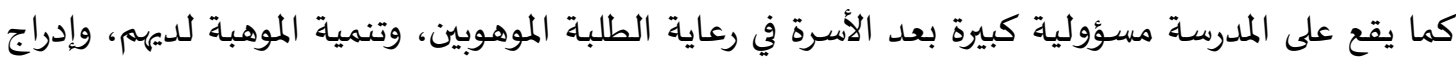

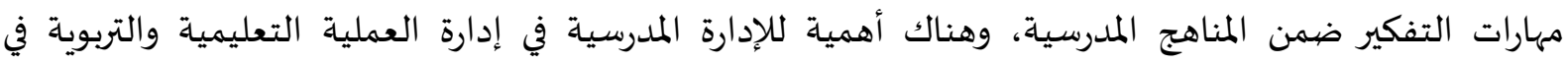

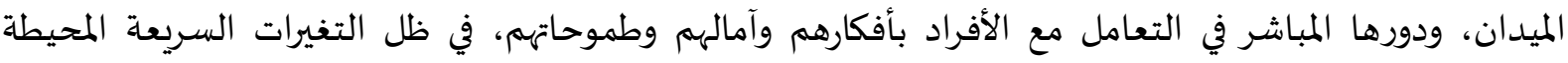

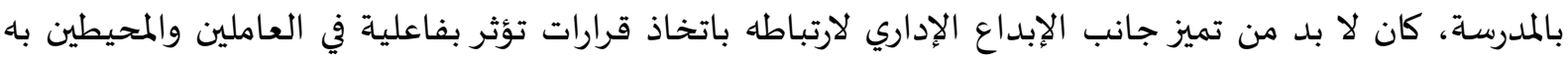

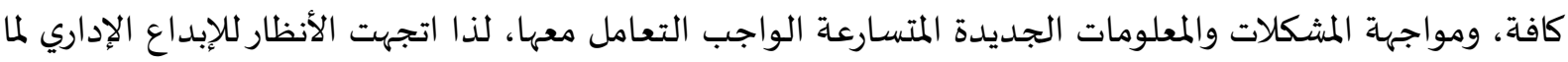
يمثله من وسيلة لاتخاذ القرارات (نصر، 2008)

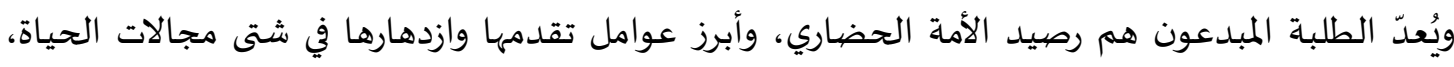

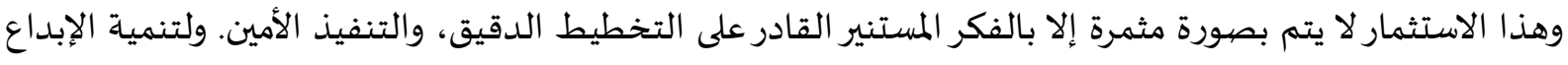

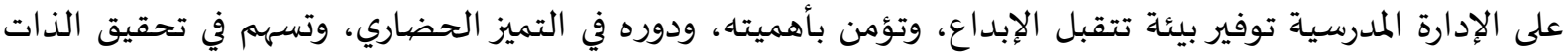

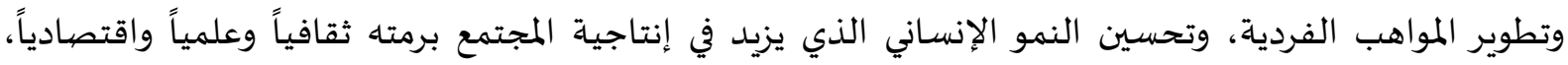

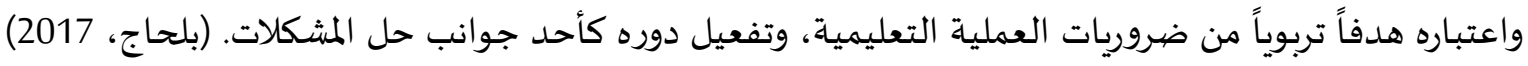

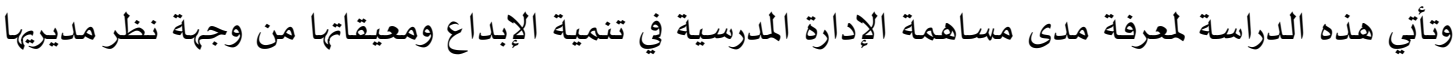

في المدارس الحكومية في مديرية لواء الجامعة.

مُشكلة الدراسة :

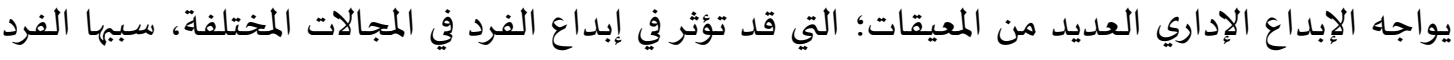

نفسـ أو الآخرون (الكاف، 2013).وقد حظي موضوع معيقات الإبداع باهتمام الكتاب والباحثين، كما جاء في دراسة 
المجدوبي (2020)، ودراسة مصطفى (2018)، ودراسة شيريل وكاثرين (Sherelles\&Catherine, 2017). حيث تناولت

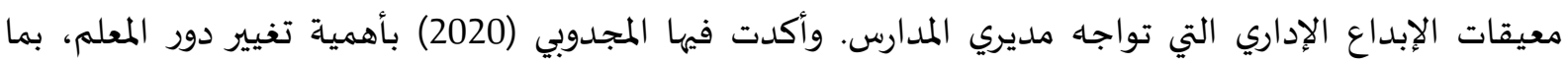

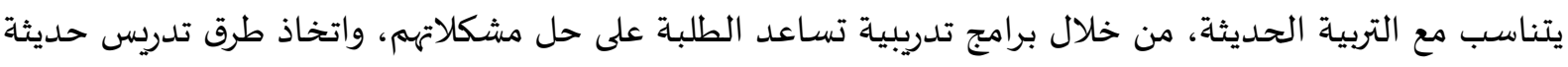

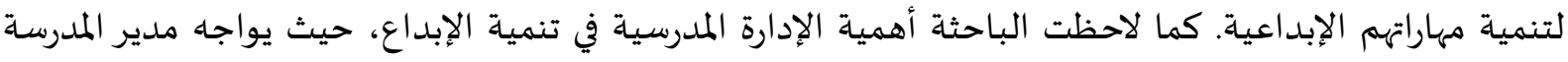

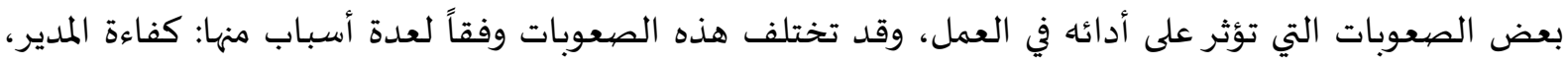

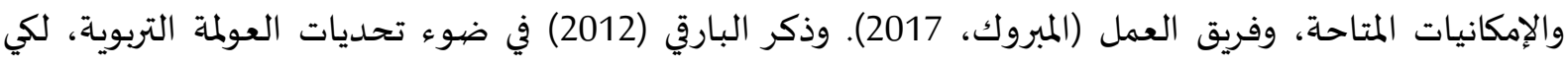

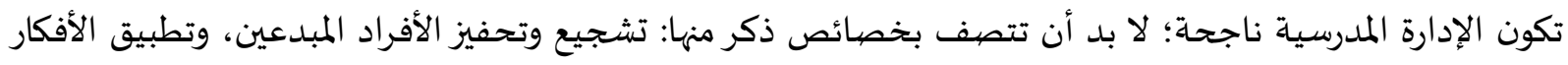

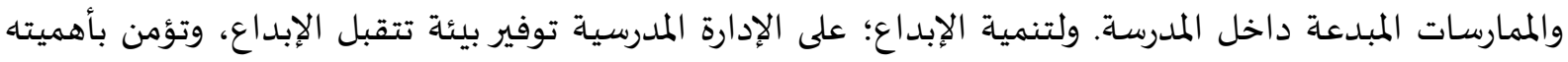

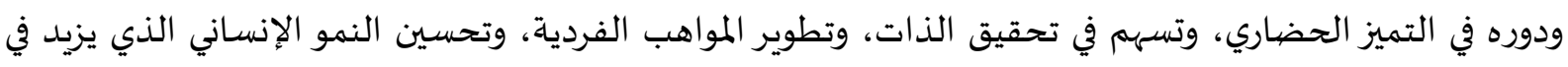

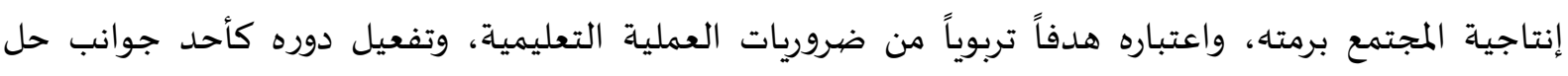

$$
\text { المشكلات (بلحاج، 2017) }
$$

كما اقترن نجاح مدير المدرسة في القيام بدوره بفاعلية بمدى إيلائه جانب التطوير الذاتي لنفسهاه، وما لدياه

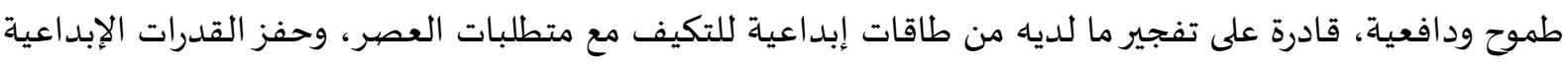

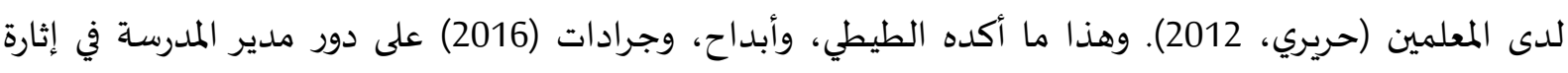

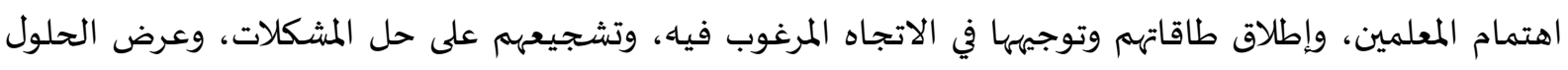
المناسبة التي تؤثر على مستوى تحصيل الطلبة.

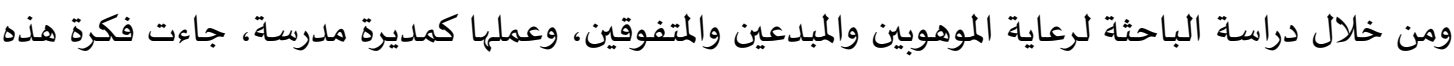

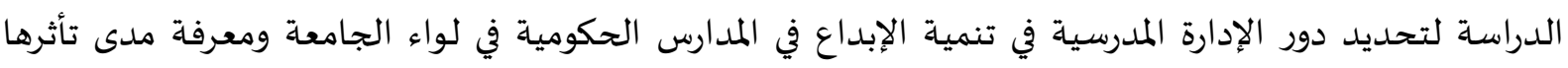
بمتغيرات (الجنس، والمؤهل العلمي، وسنوات الخبرة، ومستوى المدرسة).

أسـئلة الدّراسـة

تتحدد مشكلة الدراسة في الأسئلة الآتية:

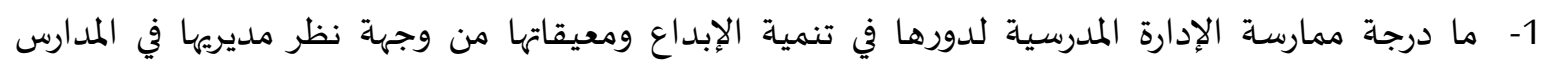

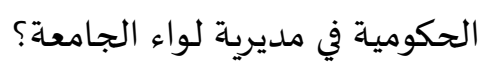

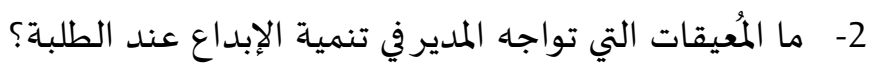

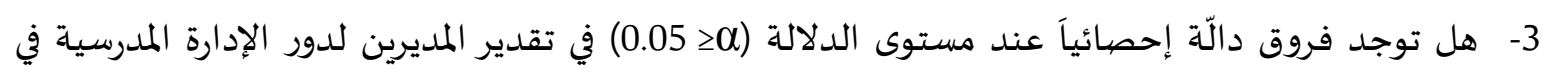
تنمية الإبداع ومعيقاتها في المدارس الحكومية في مديرية لواء الجامعة تُعزى إلى متغيرات (الجنس الجسئ والمؤهل العلمي وسنوات الخبرة ومستوى المدرسة) ؟

هدفت هذه الدّراسة لمعرفة ما يلي: 1- تحديد درجة ممارسة الإدارة المدرسية لدورها في تنمية الإبداع ومعيقاتها من وجها لنها نظر مديرهيها في المدارس الحكومية في مديرية لواء الجامعة. 2- التوصيّل إلى أهم المعيقات التي تواجه المدير في تنمية الإبداع عند الجاهده الطلبة. 


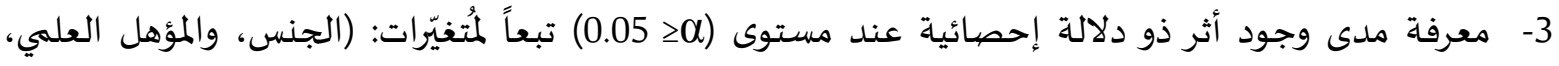

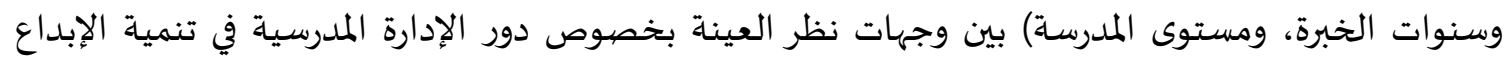

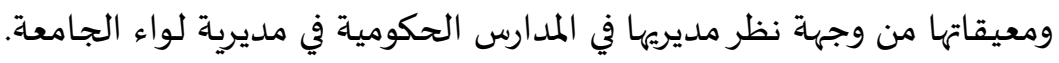

أهمية الدراسة

تأتي أهمية هذه الدراسة من جدّة وحداثة موضيوعها؛ إذ تسعى إلى التّعريف بأهميّة الإدارة المدرسية ودورها

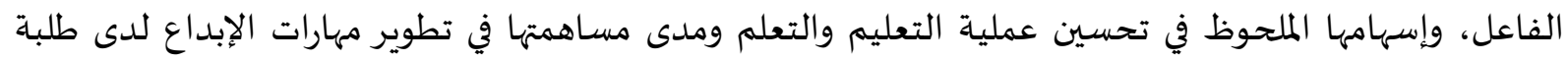
المدارس. وبحث مُعيقات استخد امها من وجهاة نظر مديريها.

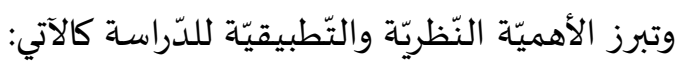

الأهميّة النظريّة

- - توفّر هذه الدّراسة للباحثين التّربوينن إطارًا نظريًّا يحوي بعض الأساسيّات والمُرتكزات النظريّة لدراسات

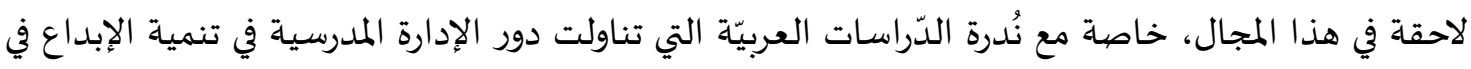

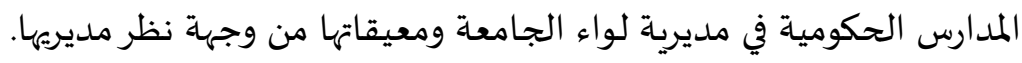

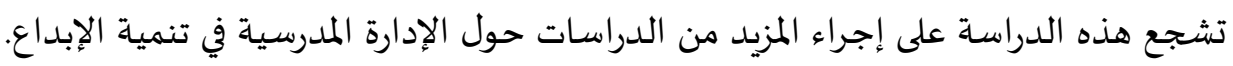

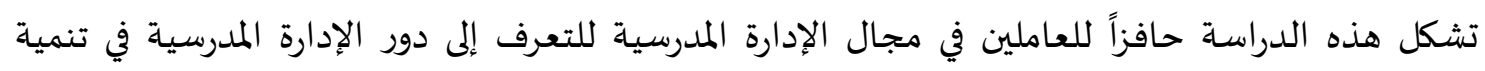
الإبداع في المدارس الحكومية من أجل تعريفهه بطرق الإدارة المدرسية في تنمية الإبداع. توضيح معيقات الإبداع في المدارس الحكومية من أجل التغلب علئ عليها.

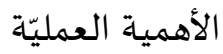

تبرز الأهمية العملية للدّراسة من خلال: - قد تساعد الإدارة المدرسية في تعرّف أدوارهم في تنمية الإبداع. - قد تساهم هذه الدّراسـة في زيادة تحصيل الطلبة العلمي ومهارات التفكير الإبداعي.

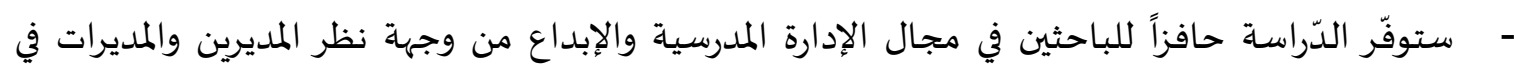
المستقبل.

تتحدد نتائج الدراسة بالحدود التالية: الحدود الموضوعية: درجة ممارسـة الإدارة المدرسية لدورها في تنمية الإبداع ومعيقاتها من وجهة نظر مديريها في المدارس الحكومية في مديرية لواء الجامعة.

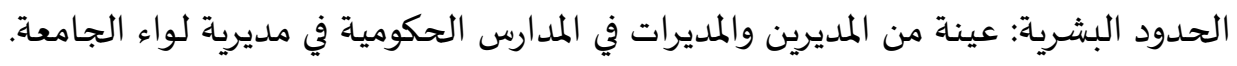

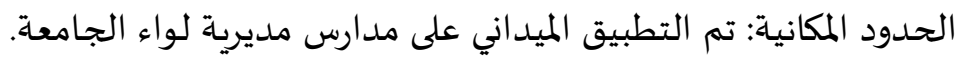

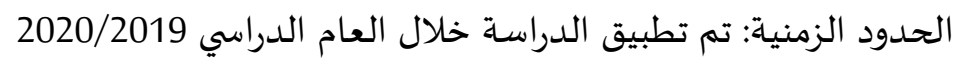
مُصطلحات الدّراسة استندت هذه الدّراسة إلى عدد من المُتغيّرات وقد جرى تعريفها كما يأتي:

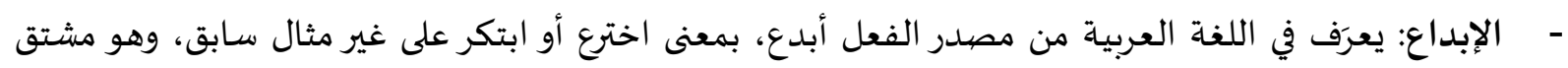

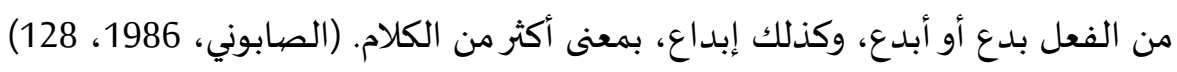


وفي القرآن الكريم: (بديع السماوات والأرض): أي خالقهما على غير مثال سبق، (سورة البقرة، الآية 117).

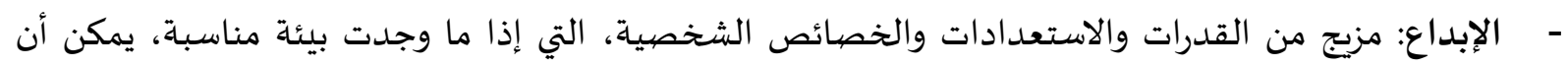

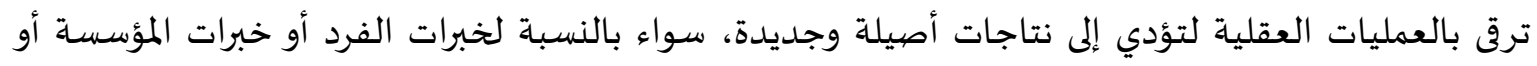

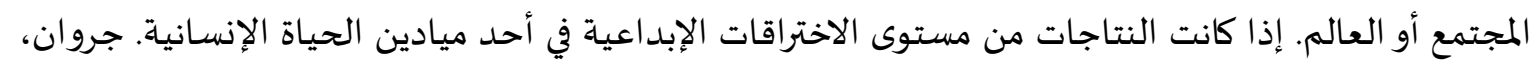

- الإبداع الإداري: يعرفه السكارنة (2011، 48) بأنه القدرة على ابتكار أساليب ووسائل وأفكار مفيدة للعمل بحيث تلقى هذه الأفكار والأساليب التجاوب الأمثل من قبل العاملين، وتحفيز ما لديهم من قدرات ومواهب لإنب لتحقيق

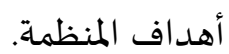

O الإبداع الإداري إجرائياً: هو استجابات المديرين في الإدارة المدرسية لتنمية الإبداع كما تحددها أداة الدراسة.

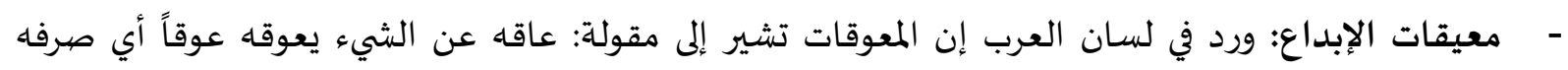

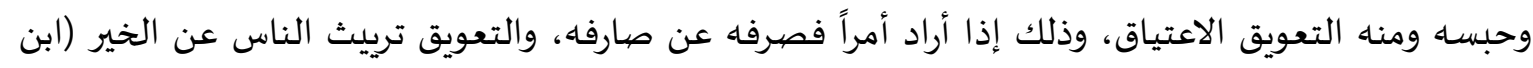

منظور، د.ت، 279)

O إجرائياً: هي العوامل التي ترتبط بالمنظومة التعليمية، وتعيق المدير في المدارس الحكومية في لواء الجامعة على

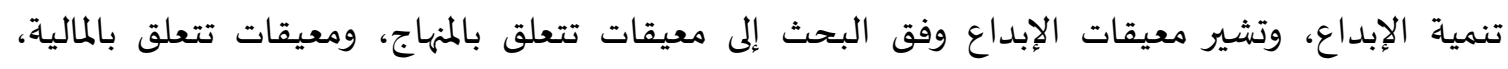

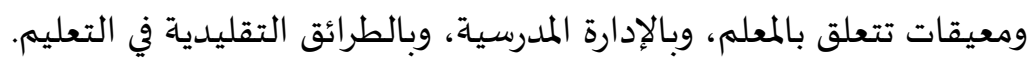

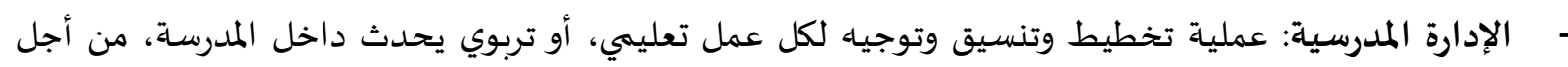
تطور وتقدم التعليم فيها. (عطوي، 2015، 18). ويعرف المدير اجرائياً بأنه: الشخص فئام المعين من وزارة التربية والتعليم في لواء الجامعة لقيادة العمل داخل

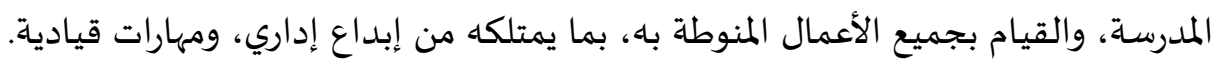

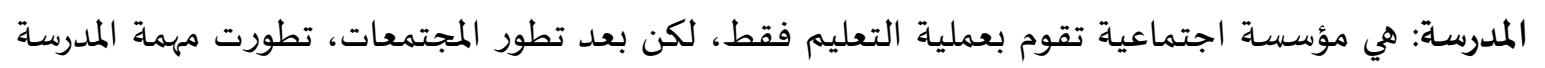

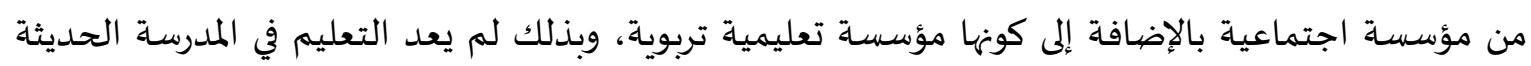

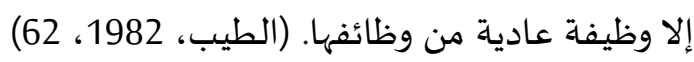
المدارس الحكومية: هي المدارس التي تشرف عليها وزارة التربية والتعليم الأردنية، وتشمل المدارس الأساسية والثانويـة. مديرية لواء الجامعة: هي إحدى مديريات الوسط التي تشرف عليها وزارة التربية والتعليم. ويضهم هذا اللواء كل

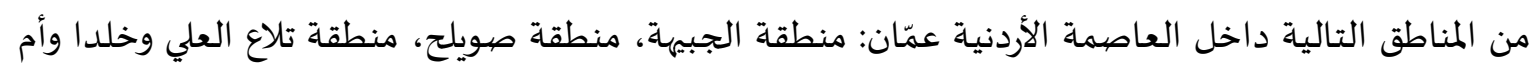
السماق، منطقة أبو نصير، منطقة شفا بدران، منطقة الكمالية.

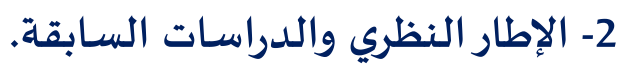

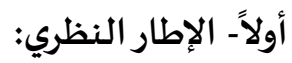

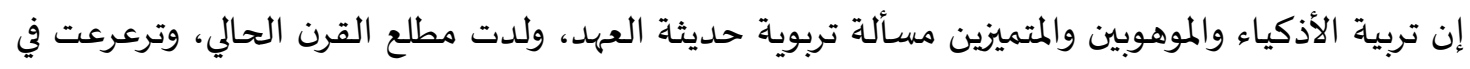

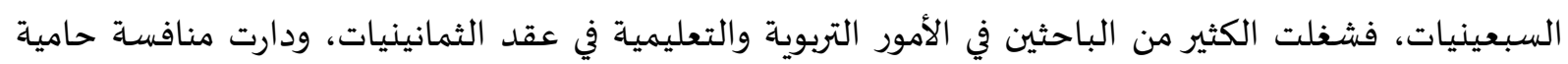

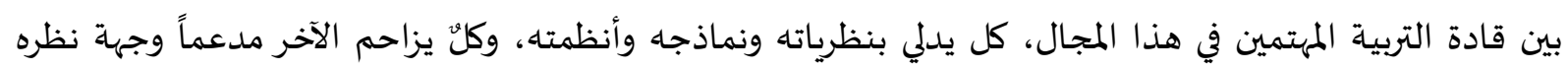
بكثير من الأبحاث والدراسات (السرور، 2010) 
ويستخدم مصطلح الإبداع مقروناً بالإدارة المدرسية، أو أي مؤسسة بشكل عام، فإنه يحمل مضامين

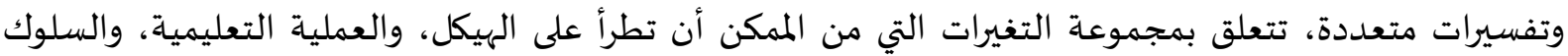

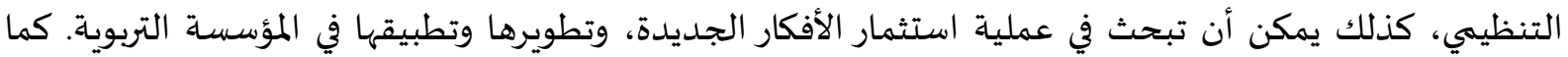
يلاحظ أن الإبداع الإداري إبداع جماعي مؤسسي، وهو أعم وأشمل من الإبداع الفردي، ويعني القدرة على ابتكار أساليب وأفكار يمكن أن تلقى التجاوب الأمثل من العاملين، وتحفزهم لاستثمار قدراتهم ومواهبهم، لتحقيق الأهداف التنظيمية والتربوية بصورة أفضل، وأكثر فائدة للعملية التربوية عامة. (السعدية، 2011)

$$
\text { مهارات التفكير الإبداعي: }
$$

يذكر (وليامز) عدة جوانب أساسية يتكون منها الإبداع وهي على النحو التالي:

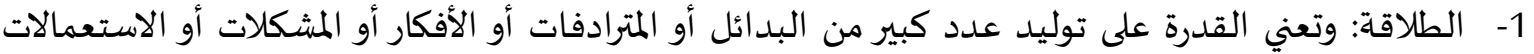

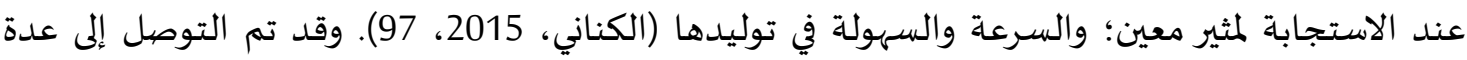
أنواع للطلاقة عن طريق التحليل العاملي، وفي ما يلي تفصيل لهذه الأنواع: الطلاقة اللفظية أو طلاقة الكلمات، وطلاقة المعاني أو الطلاقة الفكرية، وطلاقة الأشكال.

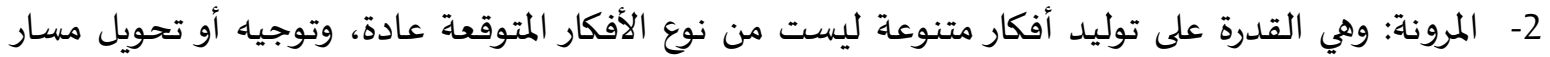

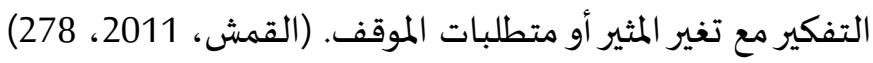

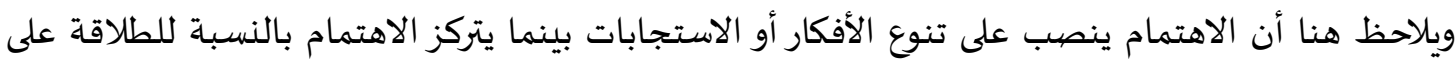
الكم دون الكيف والتنوع. 3- الأصالة: وهي تعني الجدة والتفرد، وهي العامل المشترك بين معظم التعريفات التي تركز على النواتج الإبداعية

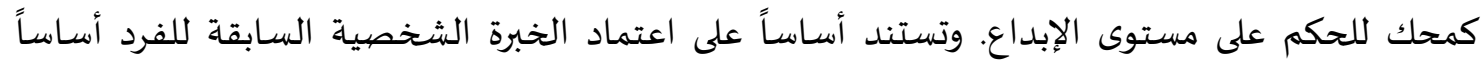

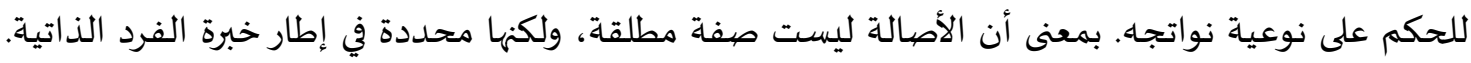

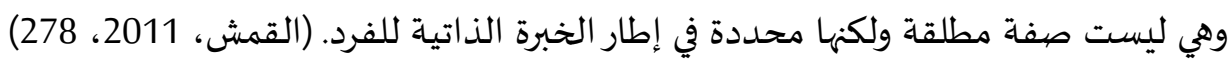
4- الإفاضة (التفاصيل): وهي تعني القدرة على إضافة تفاصيل جديدة ومتنوعة لفكرة أو حل لمشكلة أو لوحة

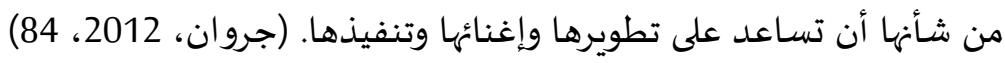

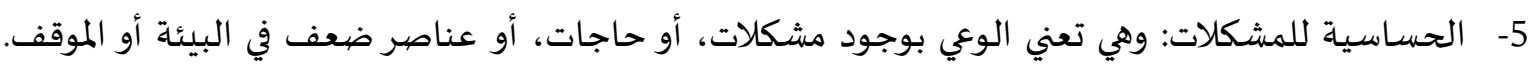

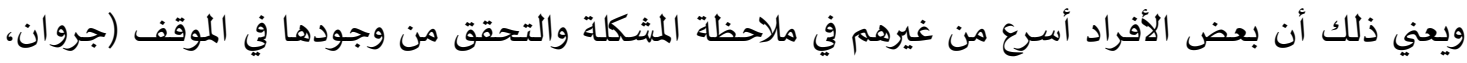

$$
\text { خصائص ومميزات الإبداع الإداري للعمل المدرسي }
$$

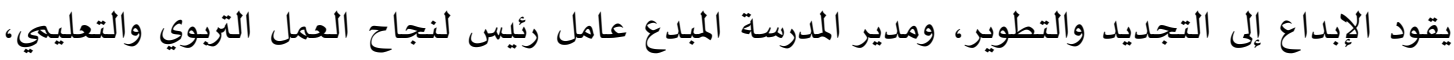
وتعتبر هذه الظاهرة التي تهتم بها المجتمعات المتقدمة، حيث تستطيع المدرساة أن تواكب ركب الحضيارة، وأن تتعامل

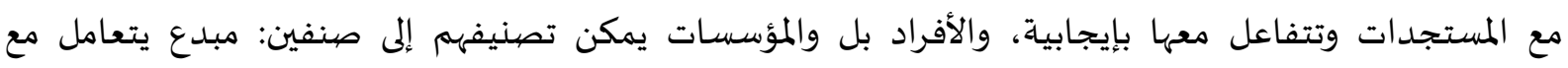
الحضارة المعاصرة بكل ثقة وبدون تخوف متجدد في فكره، وآخر مقلد ينتظر من الآخرين أن يمنوا عليه بفكرهم

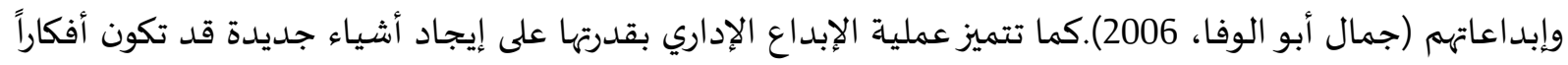

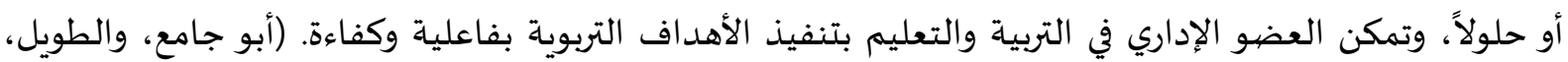




$$
\text { سمات المدير المبدع: }
$$

يمتلك جميع الناس الأسوياء قدرة على الإبداع والابتكار، وكذلك العاملين في المجال التربوي والتعليمي،

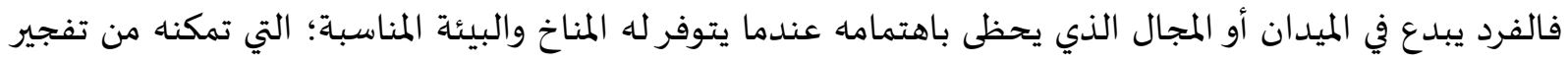
طاقاته الإبداعية، وقد يتمتع المبدعون بصفات سلوكية ونفسية تميزهم عن الآخرين، فهم مميزون باهتماماتهم ومواقفهم ودوافعهم أكثر من تميزهم بقدراتهم العضلية (Bush, 2008)

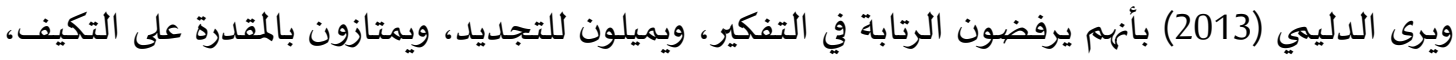

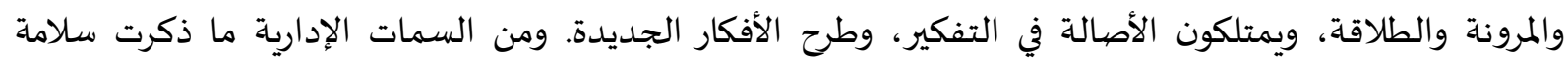

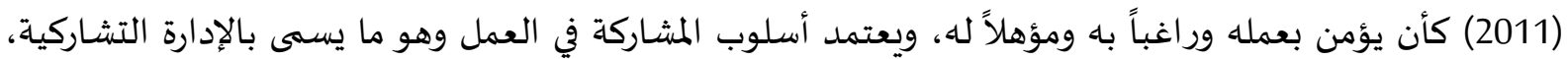
كما أن لديه القدرة على تفويض الصلاحيات، ويمتاز بالاتزان الشخصي والانفعالي. ويضيف العبيدي وآخرون (2010)

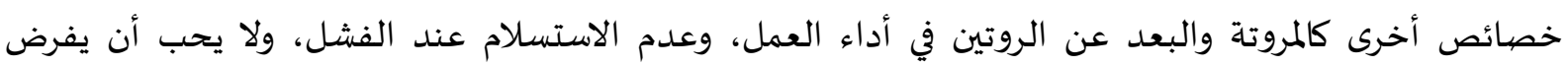
سلطته على الآخرين.

ومن الخصائص الشخصية والدافعية الميل إلى المخاطرة، وتقبل الغموض، والتمتع بشخصية مبادرة،

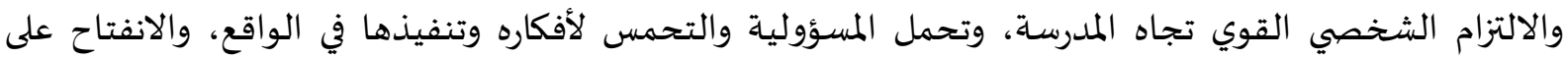

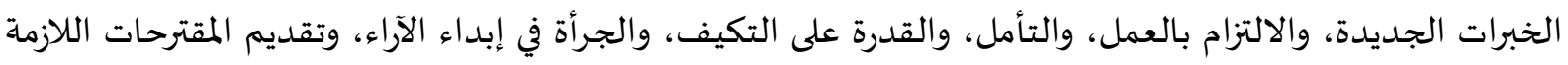
(يونس، 2000)

أما الخصائص المعرفية تتمثل في حب القراءة والميل إلى البحث والتحقيق، واستخدام المعرفة الموجودة

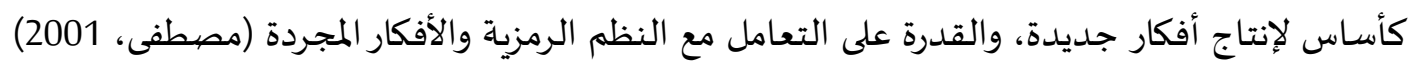

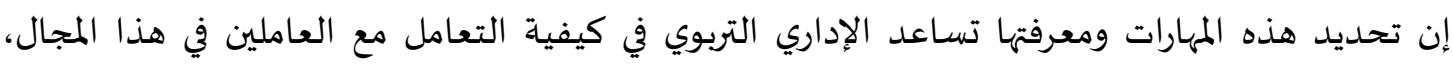

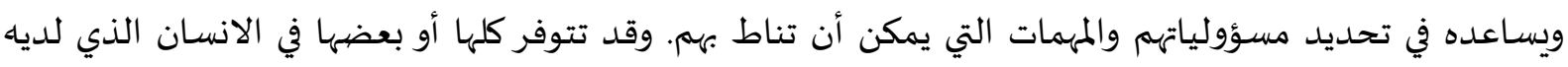

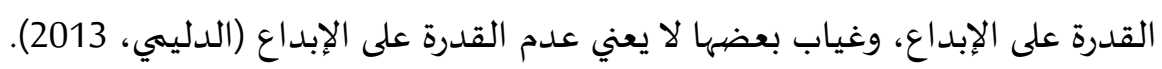

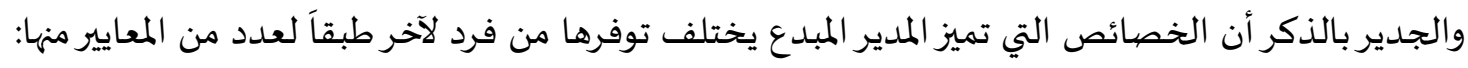
البيئة التي نشأ فيها المدير، ودرجة الاستعداد الشخصي عنده، والمواقف التي تعرض لهان التها، والأقران، وفرق العمل

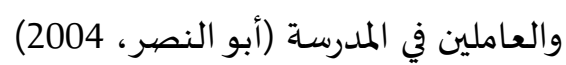

إن استخدام السلوك الإبداعي للمديرين يحدد المشكلة بدقة، ويزيد من القدرة على حلها، نظراً لإنتاج أفكارا

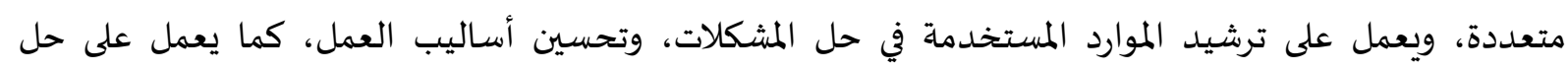

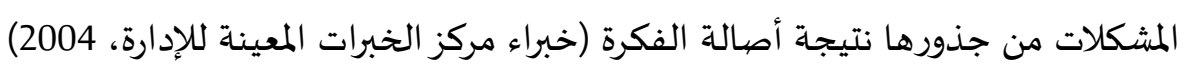

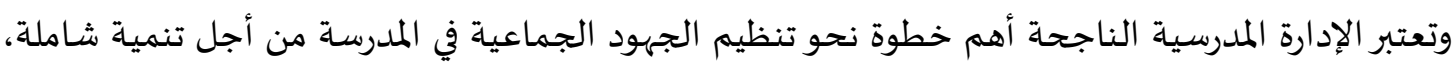

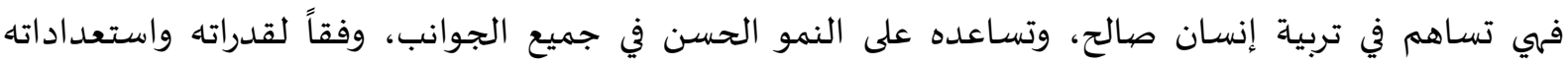
واتجاهاته (طافش، 2004).

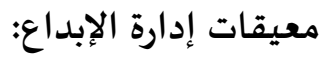
أفاد جروان (2009) إلى وجود معوقات أو عقبات كثيرة تحول دون تنمية التفكير الإبداعي، سواء على مستوى الفرد أو الجماعة أو المدارس، التي تتداخل مع بعضها البعض، التي تؤثر بدورها السلبي على أداء الماء المديرين

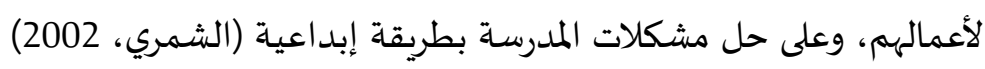


وفي دراسة قام بها طامي (2013) ذكر فيها جملة من المعيقات والتحديات التي تقف عائقاً أمام تربية الإبداع

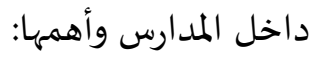

1- معيقات المناهج المدرسية: يتجلى هذا التحدي بشكل ملموس من خلال المناهج الدراسية المفروضية أو المتبعة،

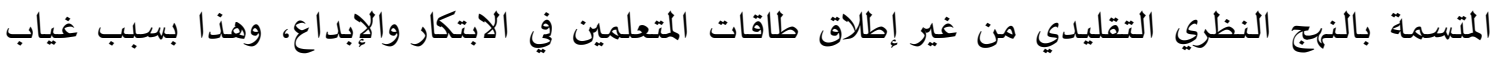
التخطيط أوسوء الإدارة، وهذا يعتمد على القائمين على هذه العملية.

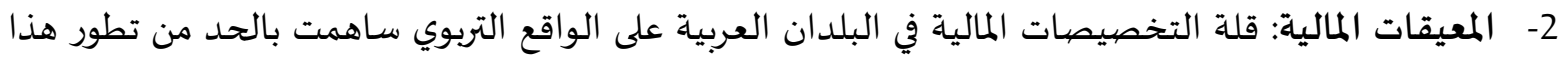
القطاع المهم، قلة المصادر المالية أدت إلى عدم تمكن بعض الدول العربية من الوصيول إلى المستوى اللازم في تجهيز المدارس بالمختبرات، والمصيادر، وكافة المستلزمات الأخرى.

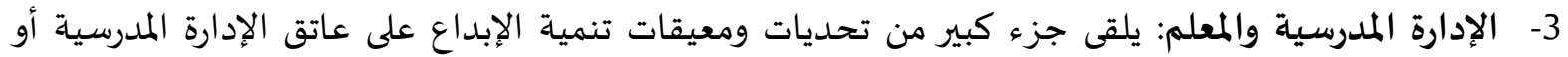

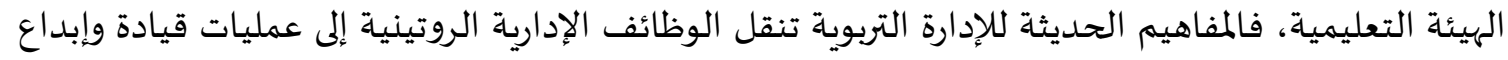
وابتكار قوامها التخطيط والتنسيق والتنظيم المؤسسي الشموليه

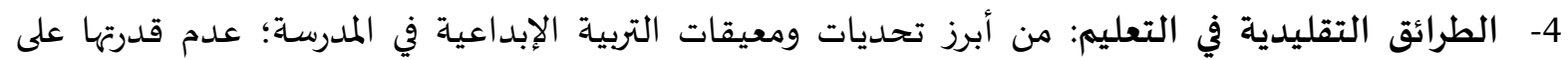
احتواء معطيات التطور المتسارعة في هذا العصر، والسبب يعود إلى اعتماد الطرائق التقليدية في التعليم

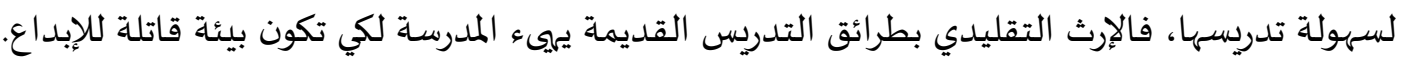

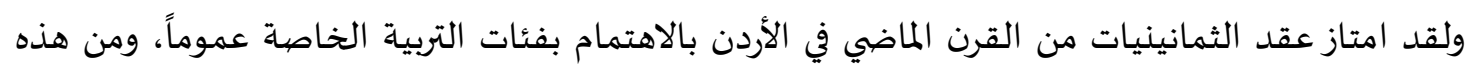

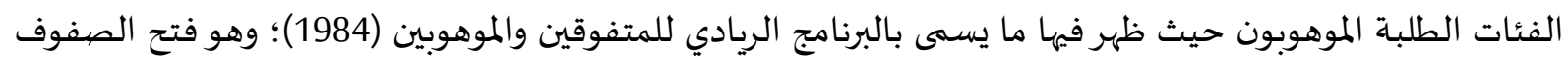
الخاصة بالموهوبين والملحقة بالمدرسة العادية، ويتضمن برنامجها الدراسي عدداً من الأنشطة ويستخدم فيها فيها طرائق تدريس حديثة (مؤسسة اعمار السلط، 1984)

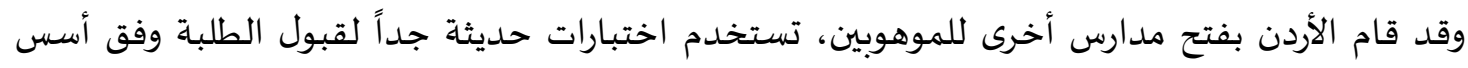

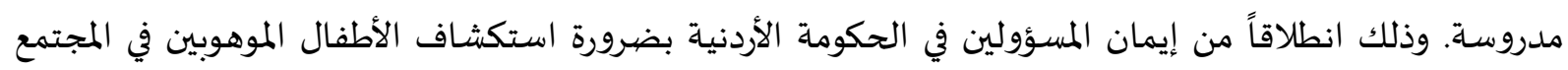

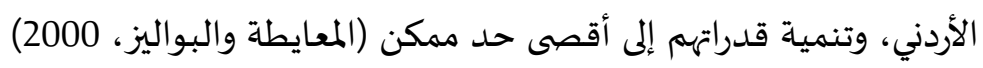
وقد اهتمت وزارة التربية والتعليم في العالم العربي بعملية تدريب مديري المدارس والمعلمين والمين وتأهيلهم، وذلك لمواكبة التجديدات والتطورات الحديثة في العملية التعليمية التعلمية، ولكونهم قادة تربويون في مدارسههم، يؤثرون في المعلمين والطلبة على حد سواء، ويحفزون على الإبداع والابتكار، من أجل تحقيق الأهداف المنشودة ومواجهات

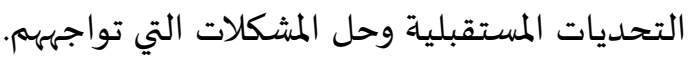

ثانياً - الدّراسـات السيّابقة هناك دراسات تعرضت إلى الإبداع الإداري ومعيقاته من منظور تربوي، وهنا سوف يتم استعراض أهم تلك

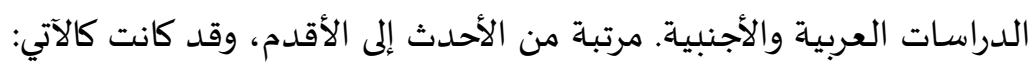
- - هدفت دراسة العنزي (2020) إلى التعرف على أهم معيقات تنمية التفكير الإبداعي لدى تلدئ تلاميذ المرحلة

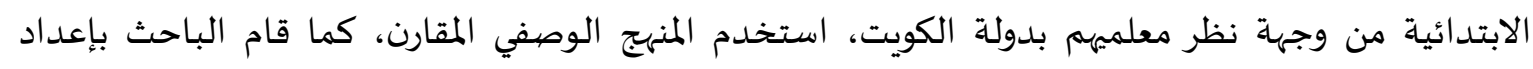

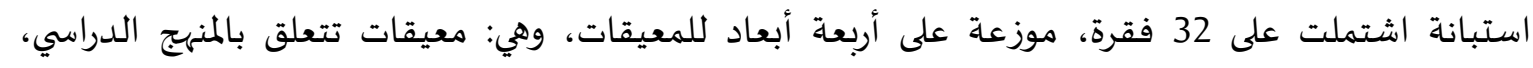

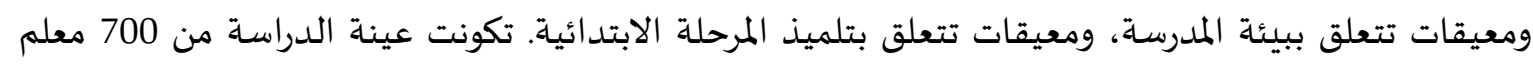

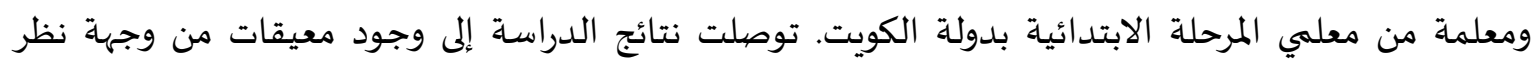


معلمي ومعلمات المرحلة الابتدائية مرتبة كالتالي: معيقات تتعلق ببيئة المدرساة، ثم معيقات تتعلق بالمنهج الدراسي، ثم معيقات تتعلق بمعلم المرحلة، وأخيراً بمعيقات تتعلق بتلميذ المرحلة الابتدائية.

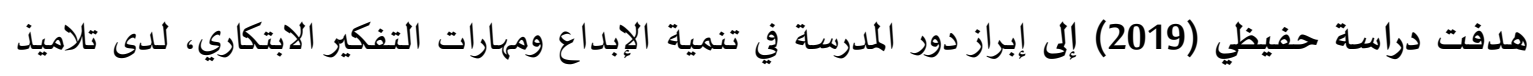

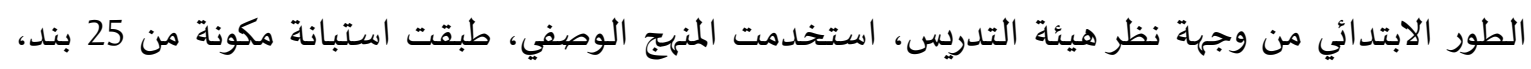

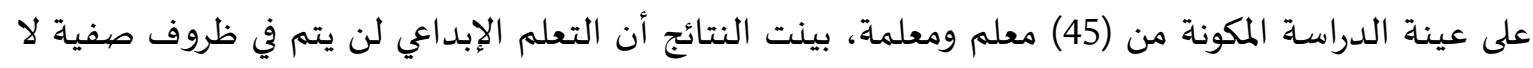

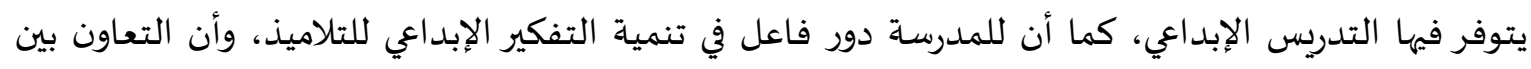
المديروالمعلم يساعد في تنمية الإبداع، ومن المعوقات عدم ملاءمة المنهاج والأساليب التعليمية لرعاية الموهوبية الإبداعين. - أجرى (أبو مديغم، حجازي، طشطوش، 2018) دراسة هدفت للتعرف إلى درجة ممارسة الإدارة المدرسية

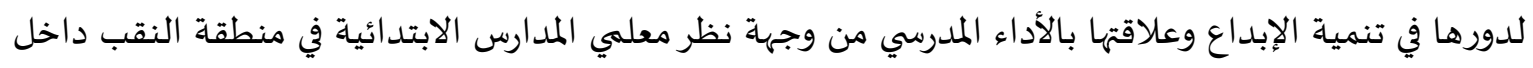

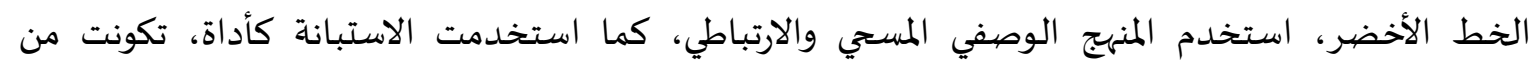

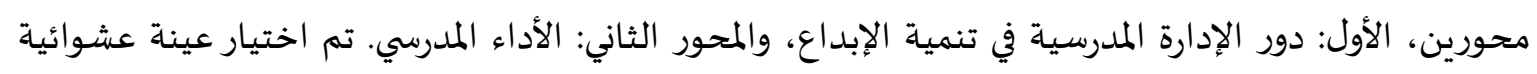

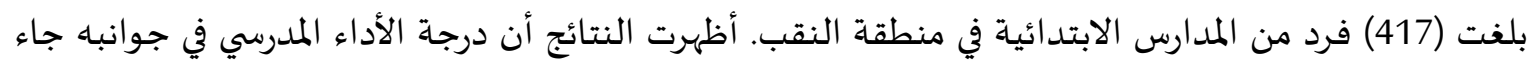

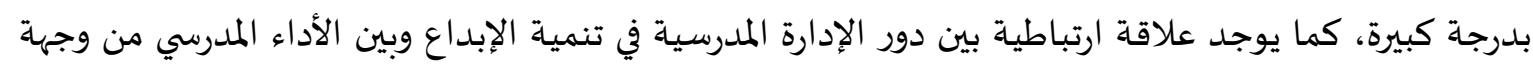
نظر المعلمين. هدفت دراسة (الحجوج، وأبو علي، 2018) إلى التعرف لدرجة ممارسة مديري المدارس الحكومية ونوابهم

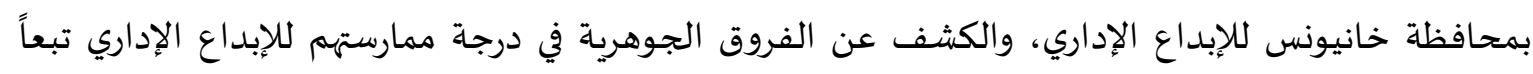

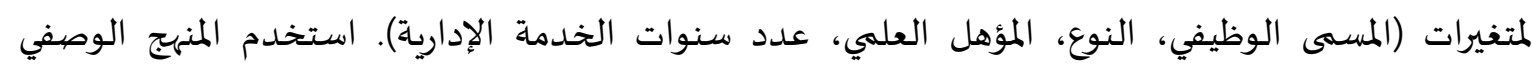
المستي، اعتمد على استبانة مكونة من (30) فقرة، تكونت عينة الدراسة من (136) مديراً ونائب مدير مدرسية.

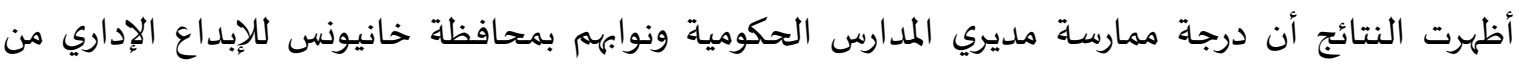

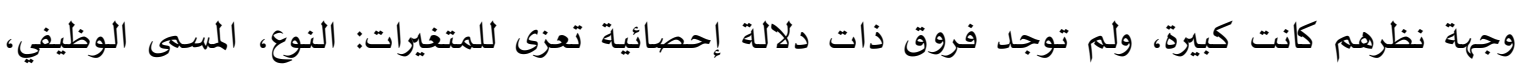
المؤهل العلمي، سنوات الخدمة في الإدارة المدرسية.

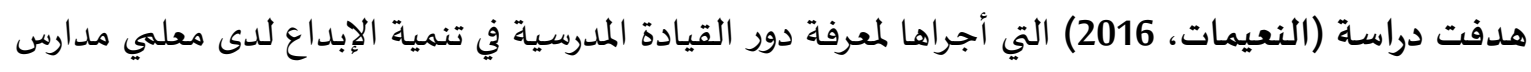

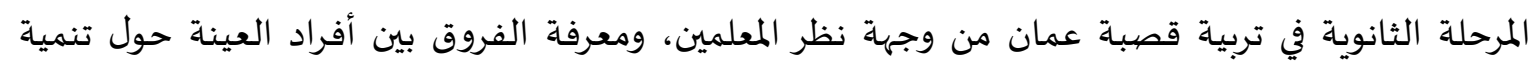

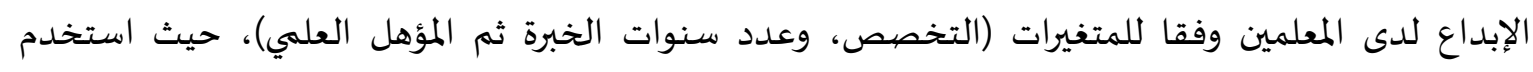

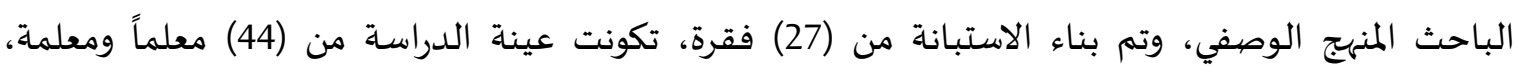

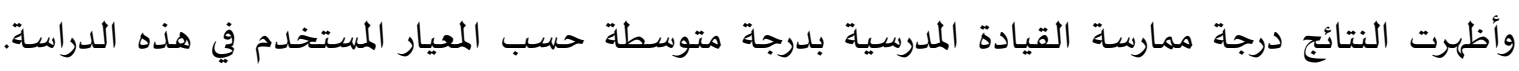

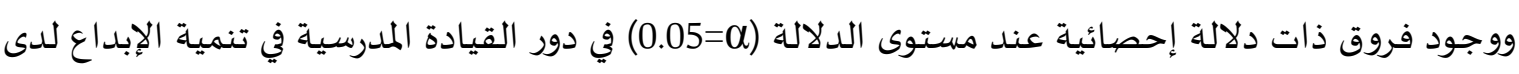

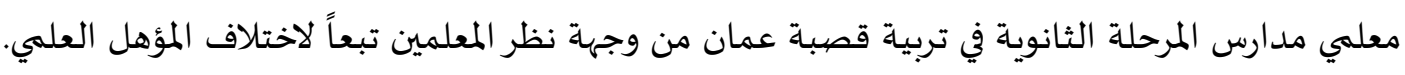
في دراسة أجرتها (السودي، 2016) هدفت إلى التعرف على مستوى الإبداع وعلاقته بالأداء الاداري لدى مديري

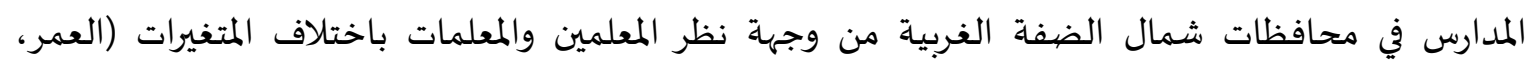

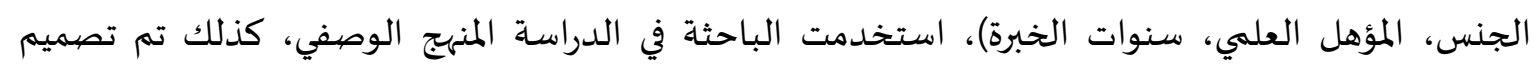

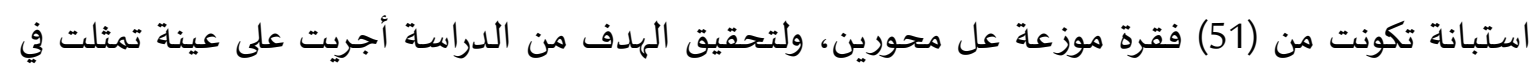

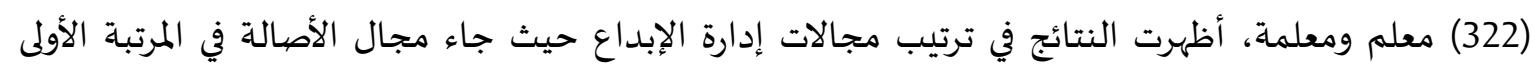

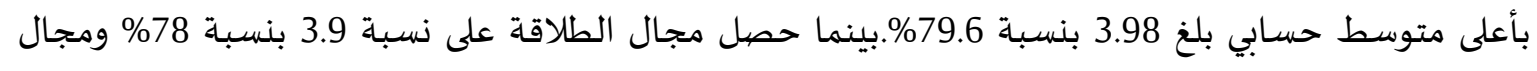

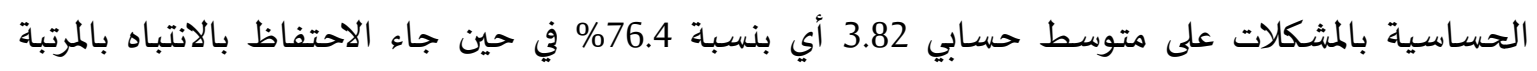


الاخيرة 3.78 بنسبة 75\%. وكذلك اتضح عدم وجود فروق ذات دلالة إحصائية عند مستوى دلالة (م=0.05) في

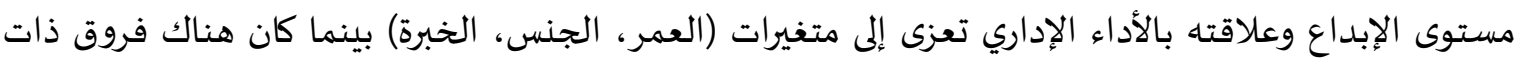
دلالة إحصائية تعزى لمتغير المؤهل العلمي. وفي دراسة أجراها (سويطي، 2015). سعت هذه الدراسة إلى معرفة دور الإدارة المدرسية في تنمية الإبداع من

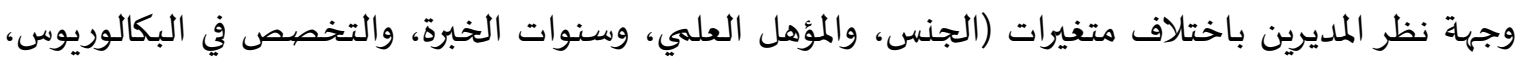

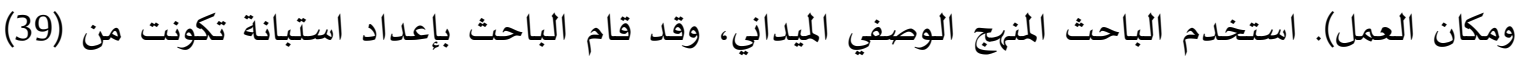

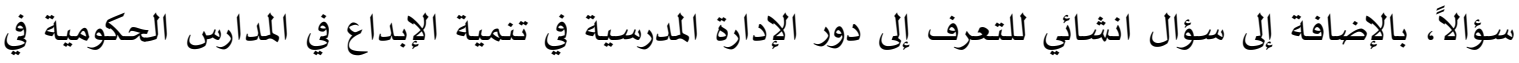

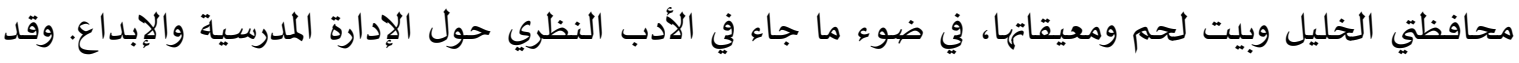
تكونت عينة الدراسة من (196) مديراً ومديرة، توصلت الدراسة إلى أن مجال المعلم في تنمية الإبداع كان كباء كبيراً

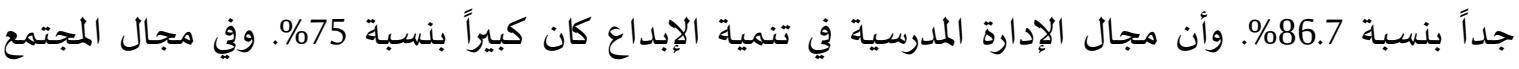

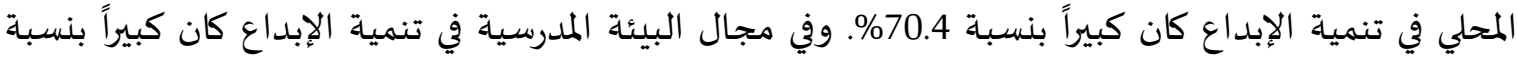

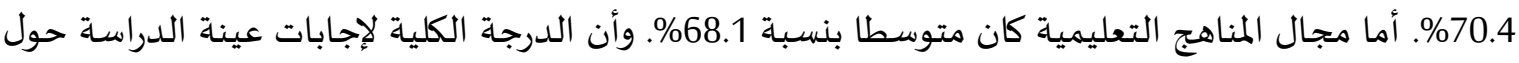

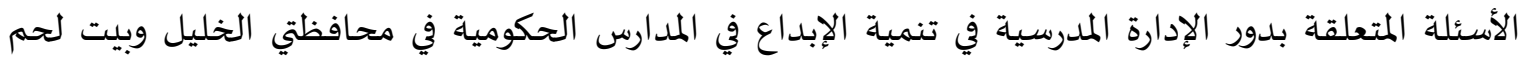

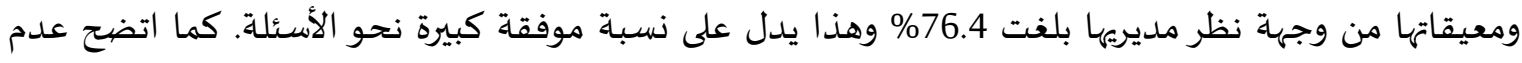

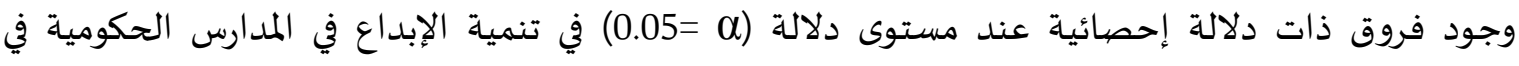
محافظتي الخليل وبيت لحم ومعيقاتها من وجهاة نظر مديريها تعزى إلى متغيرات (المؤهل العلمي، سنوات المهات الخبرة،

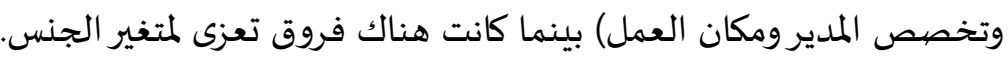

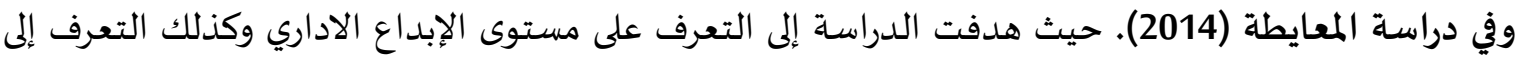

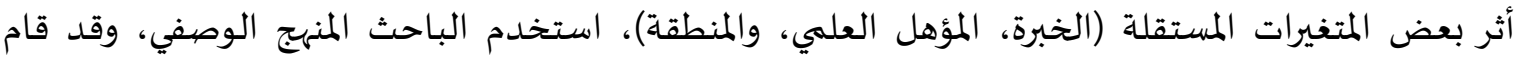
الباحث باستخدام استبانة مكونة من (52) فقرة تضيم خمسة مجالات. وقد تكونت عينة الدراسة من (164)

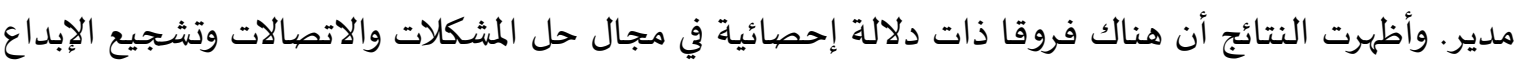

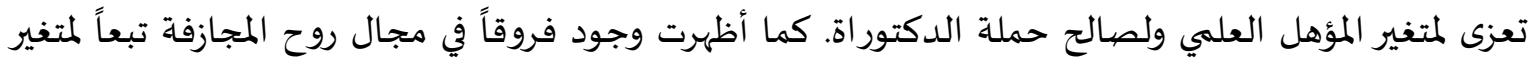
المنطقة ولصالح الوسط وفي مجال الاتصالات لصالح الشمال. وهدفت دراسة عبابنة والشقران (2013). للكشف عن درجة ممارسة الإبداع الإداري من قبل القادة التربويين

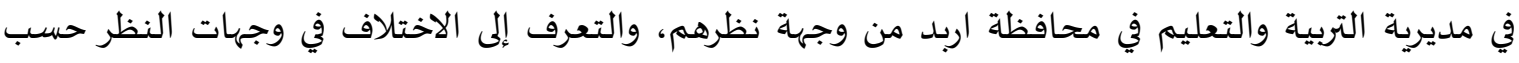

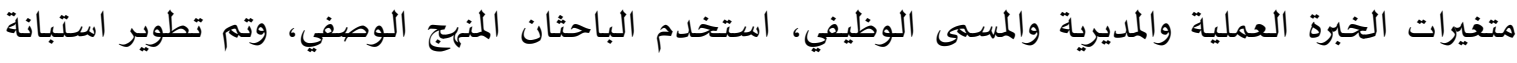

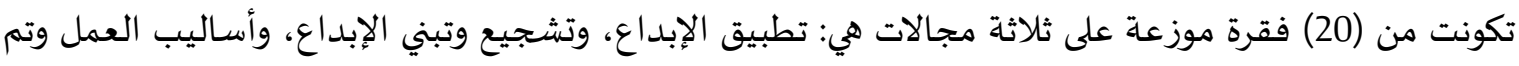

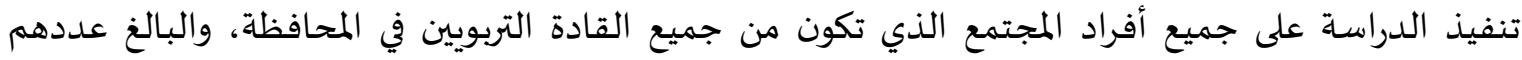

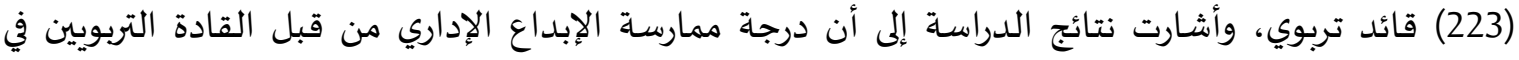

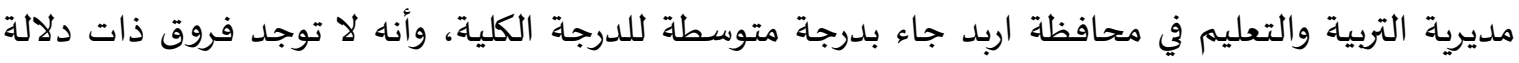

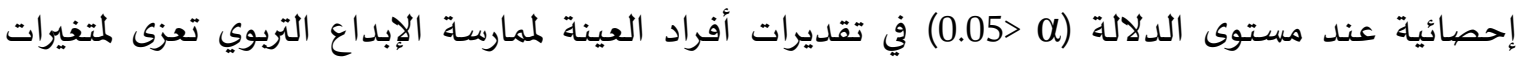

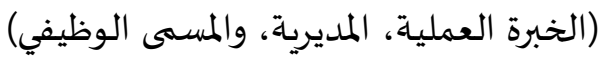
وأجرى عثمان وعبد الرحمن (Othman \& Abd Rahman, 2013) دراسة هدفت الكشف عن مهارات الإدارة

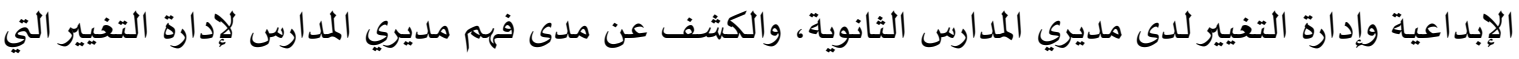

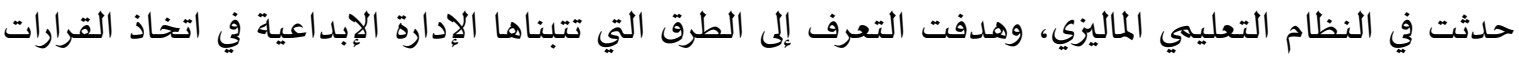


بشكل تشاركي مع المعلمين. وطرق حل المشكلات والكشف عن السمات الشخصية للقادة المبدعين والتي تبنى

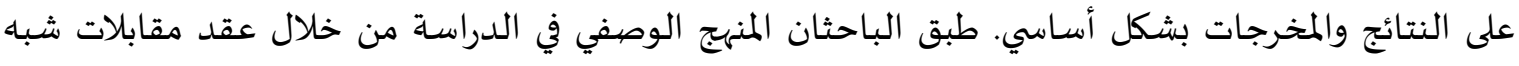

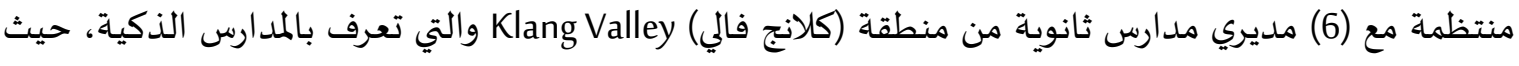

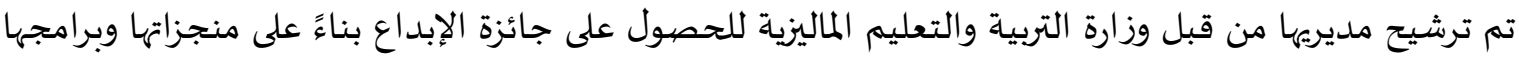

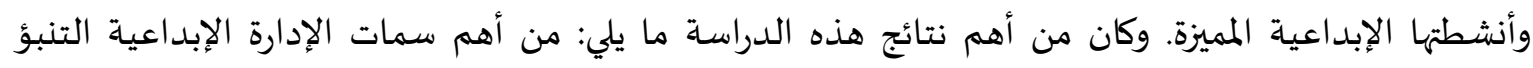

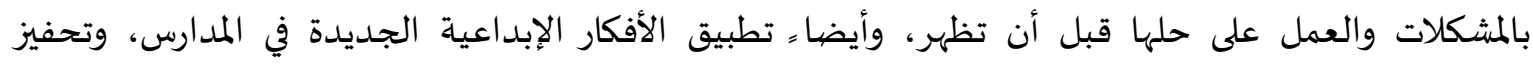

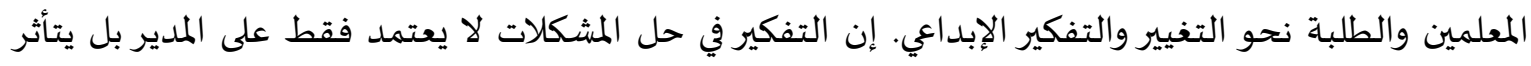
بعاملين خارجيين هما: المنظمة وعملية التغيير.

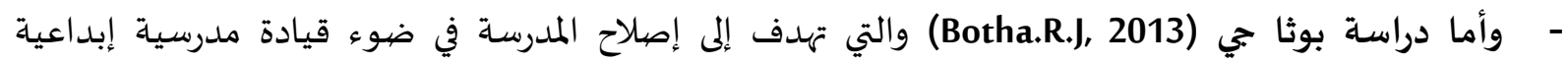

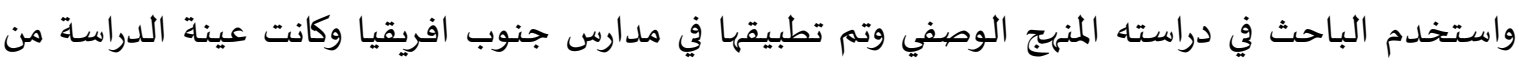

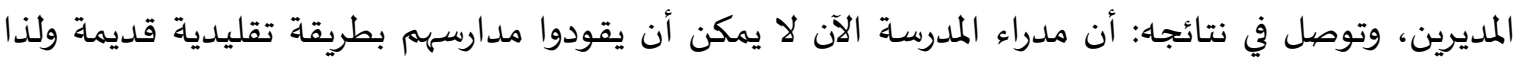

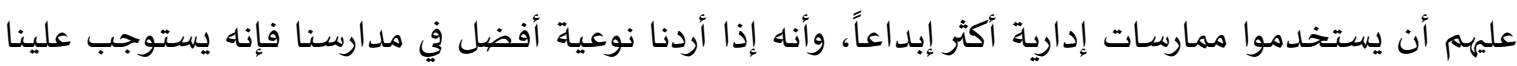
أن نقود مدارسنا بشكل مختلف تتطلب طرقاً خلاقة من التفكير. وفي دراسة زامبيتاكس وبورنتا وموستاكيس (Zamptakis \& Bouranta \&Moustakis, 2010) هدفت هذه هذه

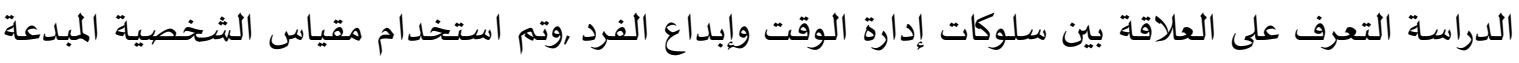

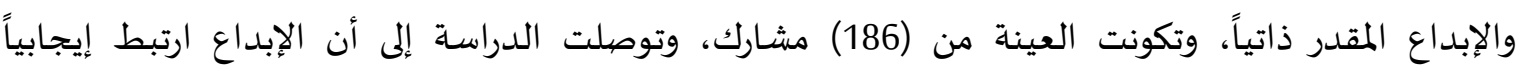

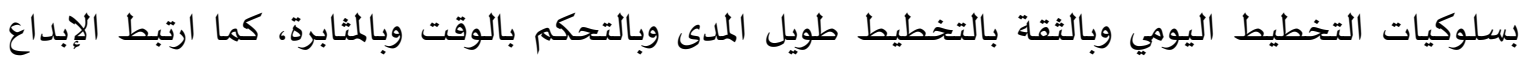
سلبياً بأولوية الفساد التنظيمي.

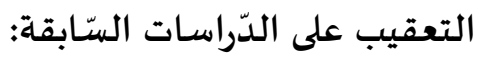

على الرغم من تنوّع أهداف الدراسات السابقة إلا أنها اتفقت معها من حيث موضوعها الدابها في دراسة تنمية

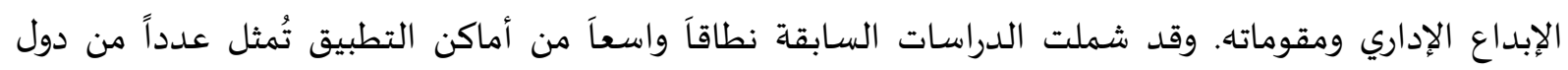

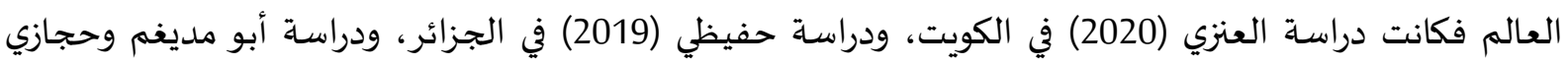

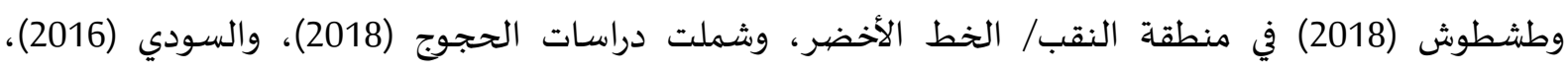
وسويطي (2015) محافظات الضفة الغبية، والنعيمات (2016) والمعايطة (2014) وعبابنة والشقران (2013) فقد وند

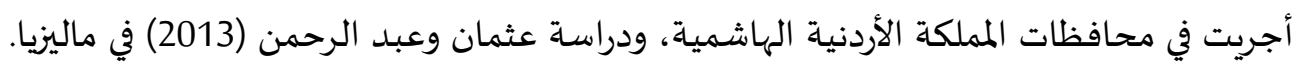
ومن جهة العينة فقد تنوعت واختلفت، كالمعلمين فقط في دراسة العنزي (2020) وحفيظئ وعيد (2019)

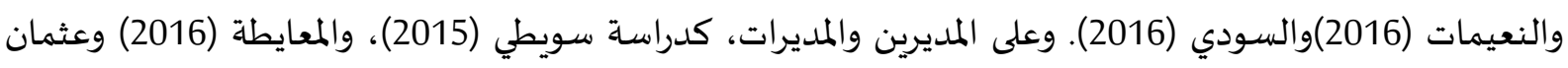

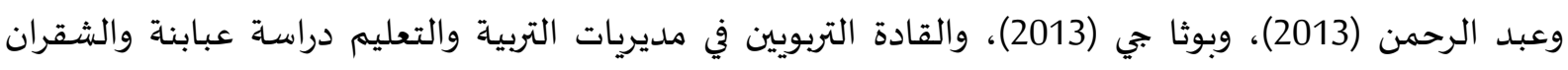

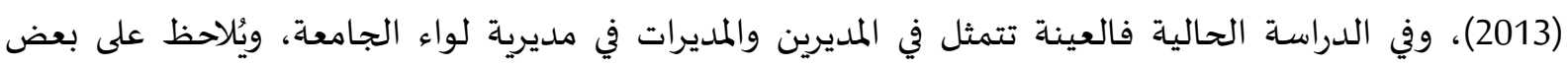

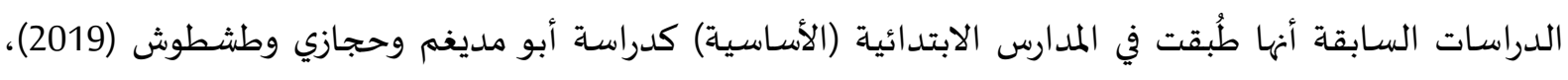

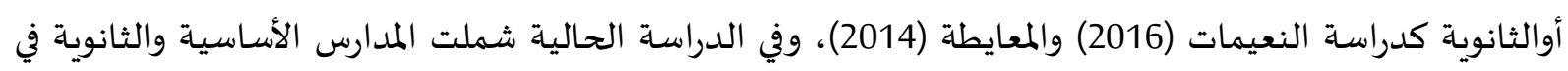
مديرية لواء الجامعة. وقد استفادت الدراسة الحالية من الدراسات السابقة في منهج الدراسـ؛ إذ استخدمت المنهج الوصفي من خلال إعداد أداة الدراسة، وهي استبانة تم إعدادها لجمع البيانات من أفراد عينة الدراسة. 
وما يميز الدراسة الحالية عن غيرها من الدراسات السابقة، تناولها لفئة مديري ومديرات المدارس الحكومية

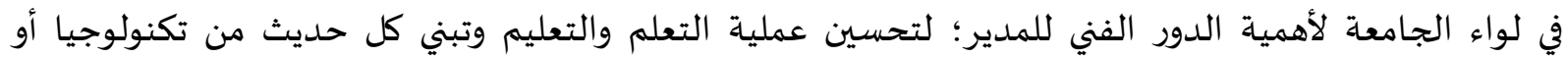
أساليب حديثة مما يزيد من القدرة على مواجهة تحديات العصر.

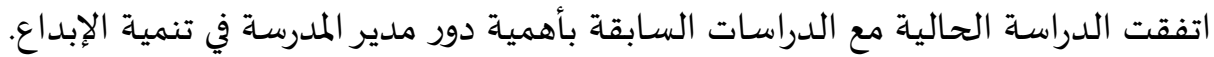
وتختلف الدراسة الحالية عن الدراسات السابقة في محاولتها معرفة دور الإدارة المدرسية وربطها بالمعيقات التي تواجه مدير المدرسة، حيث اقتصرت بعض الدراسات السابقة إما دراسة دور مدير المدرسة أو دراسة المعيقات كل على حده.

3- منهجية الدراسـة وإجراءاتها.

منهنج الدراسة:

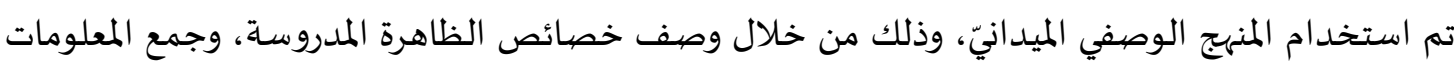
عنها، ومتابعتها في الميدان بغية الحصول على بيانات حقيقية، وتحقيق أهدافها، والإجابة عن أسئلة الدراسـة.

مجتمع الدراسة: تكوّن مجتمع الدراسة من جميع المدراء في مديرية تربية لواء الجامعة للعام الدراسي (2020/2019) والبالغ

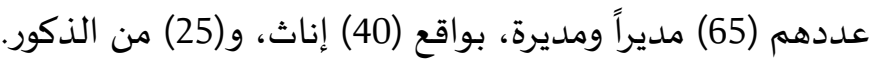
عينة الدراسة: تمّ اختيار عينة مكونة من (55) مديراً ومديرة، بما نسبته (85\%) من مجتمع الدراسة، وقد تم اختيارهم من

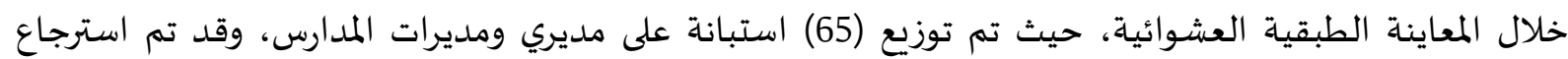
(55) (20) والجدول (1) يبين خصائص عينة الدراسة وفقاً لمتغيراتها الديموغرافية.

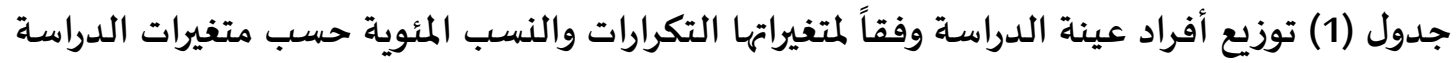

\begin{tabular}{|c|c|c|c|}
\hline النسبة & التكرار & الفئات & المتغيرات \\
\hline 38.2 & 21 & ذكر & \multirow{2}{*}{ الجنس } \\
\hline 61.8 & 34 & أنثى & \\
\hline 63.6 & 35 & دبلوم عال & \multirow{2}{*}{ المؤهل العلمي } \\
\hline 36.4 & 20 & دراسـات عليا & \\
\hline 40.0 & 22 & أقل من 5 سنوات & \multirow{3}{*}{ سـنوات الخبرة في العمل } \\
\hline 23.6 & 13 & من 5- 10 سنوات & \\
\hline 36.4 & 20 & أكثر من 10 سنوات & \\
\hline 54.5 & 30 & أساسي & \multirow{3}{*}{ مستوى المدرسة } \\
\hline 45.5 & 25 & ثانوي & \\
\hline 100.0 & 55 & المجموع & \\
\hline
\end{tabular}


تبين من خلال الجدول أن نسبة الإناث (61.8\%)، بينما نسبة الذكور (38.2\%)، حيث عدد مدارس الإناث

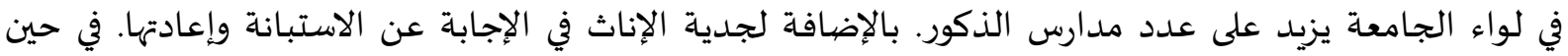
جاءت نسبة المدراء ممن يحملون شهادة الدبلوم العالي بنسبة (63.6\%) بالمرتبة الأولى، حيث لا يتم التعيين بوظيفة مدير إلا لمن يحملون شهادة الدبلوم العالي على الأقل. كما جاءت في المرتبة الأولى من كانت سنوات الخبرة لديهم أقل من 5 سنوات بنسبة (40.0\%)، ويمكن تفسير ذلك اختيار المدراء الجدد بعناية فائقة حيث يتميزون بكفاءة عالية حيث يتعرضون لتنمية مهنية قبل تعيينهم لهذه الوظيفة.

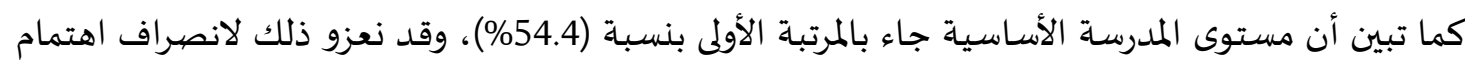

لتحقيق أهداف الدراسة قامت الباحثة بإعداد وتطوير الاستبانة لأغراض هذه الدراسة، وتتكون من قسمين

وتشتمل على البيانات الشخصية التي تمثل المدير الذي قام بتعبئة الاستبانة وضمت هذه البيانات متغيرات

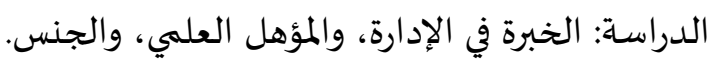
الإبداع الإداري

ويشمل على استبانة تكونت من (28) فقرة للتعرف على درجة ممارسة الإدارة المدرسية لدورها في تنمية الإبداع، و(8) فقرات للتعرف على معيقات الإدارة المدرسية.

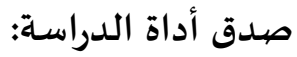
تم عرض أداة الدراسة بصورتها الأولية على مجموعة من المحكّمين المختصين من ذوي الخبرة والاختصاص

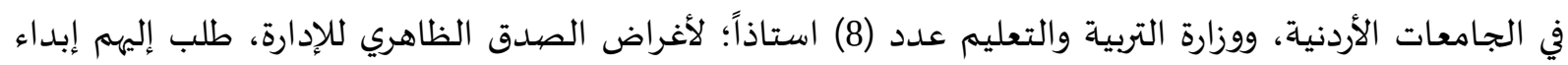

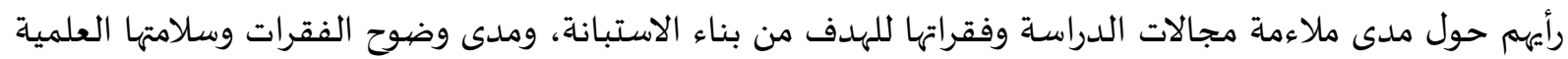

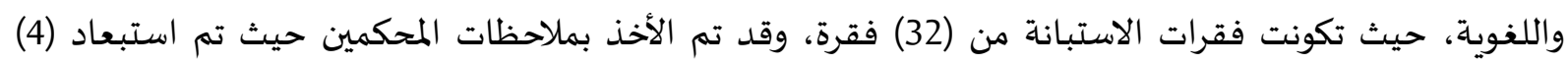
وتعديل بعض الفقرات. واستقرت على (28) فقرة لدور الإدارة المدرسية، وو(8) فقرات لكترات للمعيقات.

صدق البناء: لاستخراج دلالات صدق البناء للمقياس، استخرجت معاملات ارتباط الفقرة مع الدرجة الكلية للمحور التي تنتمي إليه في عينة استطلاعية من خارج عينة الدراسة تكونت من (20) مدير ومديرة، وقد تراوحت معاملات ارتباط

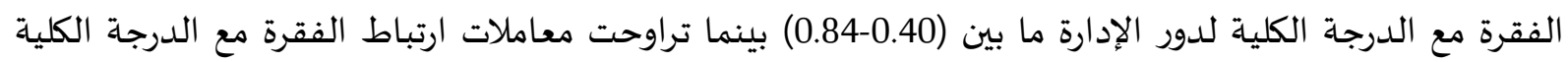

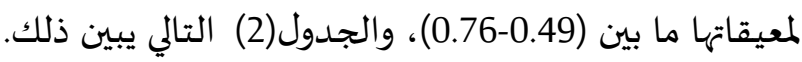
جدول (2) معاملات الارتباط بين الفقرة والدرجة الكلية للمحور التي تنتمي إليه داليه

\begin{tabular}{|c|c|c|c|c|c|}
\hline \multicolumn{2}{|c|}{ المعيقات } & \multicolumn{4}{|c|}{ دور الإدارة } \\
\hline معامل الارتباط & رقم الفقرة & معامل الارتباط & رقم الفقرة & معامل الارتباط & رقم الفقرة \\
\hline$* * .73$ & 29 & $* .47$ & 15 & $* * .74$ & 1 \\
\hline$* * .52$ & 30 & **.64 & 16 & $* .40$ & 2 \\
\hline
\end{tabular}


المجلة العربية للطوم ونشر الأبحاث ـ مجلة العلوم التربوية والنفسية ـ المجلد الخامس ـ العدد التاسع والثلاثون ـ أكتوبر 2021م

\begin{tabular}{|c|c|c|c|c|c|}
\hline \multicolumn{2}{|c|}{ المعيقات } & \multicolumn{4}{|c|}{ دور الإدارة } \\
\hline **.76 & 31 & $* * .59$ & 17 & $* * .80$ & 3 \\
\hline$* .49$ & 32 & $* * .82$ & 18 & $* * .67$ & 4 \\
\hline **.64 & 33 & **.68 & 19 & $* * .71$ & 5 \\
\hline$* * .70$ & 34 & $* * .74$ & 20 & $* * .62$ & 6 \\
\hline **.65 & 35 & $* * .72$ & 21 & $* * .53$ & 7 \\
\hline **.54 & 36 & $* * .74$ & 22 & $* * .67$ & 8 \\
\hline & & $* * .77$ & 23 & $* .43$ & 9 \\
\hline & & **.66 & 24 & $* * .84$ & 10 \\
\hline & & $* * 67$ & 25 & $* * .65$ & 11 \\
\hline & & ${ }^{* *} .61$ & 26 & $* * .68$ & 12 \\
\hline & & **.60 & 27 & $* * .70$ & 13 \\
\hline & & $* .47$ & 28 & $* .47$ & 14 \\
\hline
\end{tabular}

*دالة إحصائيا عند مستوى الدلالة (0.05). **دالة إحصائيا عند مستوى الدلالة (0.01).

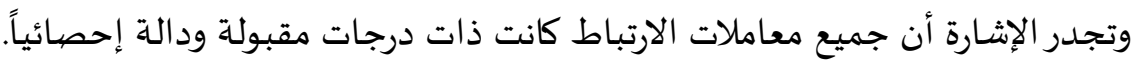

ثبات أداة الدراسة:

للتأكد من ثبات أداة الدراسة، فقد تم التحقق بطريقة الاختبار وإعادة الاختبار (test-retest) بتطبيق المقياس، وإعادة تطبيقه بعد أسبوعين على مجموعة من خارج عينة الدراسة مكوّنة من (20) مديراً ومديرة، ومن ثم تم حساب معامل ارتباط بيرسون بين تقديراتهم في المرتين.

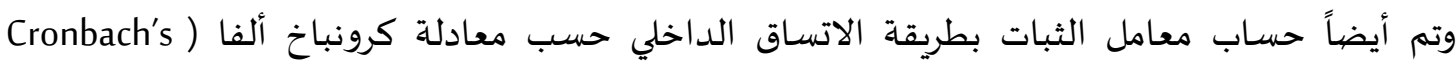

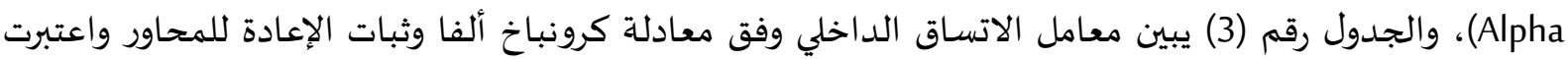
هذه القيم ملائمة لغايات هذه الدراسة. جدول (3) معامل الاتساق الداخلي كرونباخ ألفا وثبات الإعادة للمحاور

\begin{tabular}{|c|c|c|c|}
\hline الاتسـاق الداخلي & ثبات الإعادة & عدد الفقرات & المحور \\
\hline 0.89 & 0.91 & 28 & دور الإدارة \\
\hline 0.80 & 0.88 & 8 & المعيقات \\
\hline 0.85 & 0.89 & 36 & الكلي للأداة \\
\hline
\end{tabular}

الوزن النسبي

وللخروج بنتائج علمية دقيقة قامت الباحثة باستخدام مقياس ليكرت خماسي الأبعاد للإجابة عن الفقرات

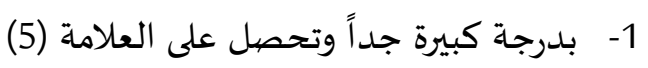

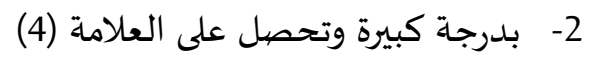

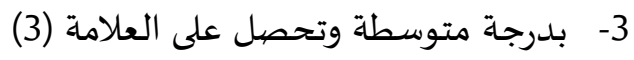


4- - بدرجة قليلة وتحصل على العلامة (2)

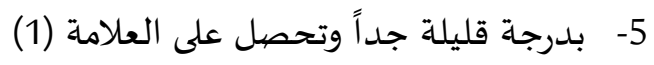

وقد طلب من المستجيبين وضع اشارة (X) أمام كل فقرة وتحت الإجابة التي يرونها مناسبة، وقد تم اعتبار

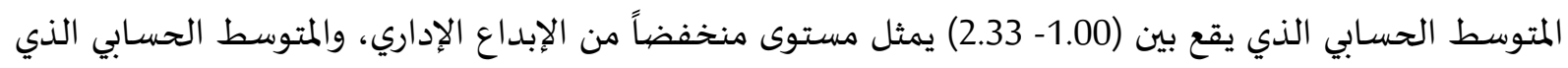

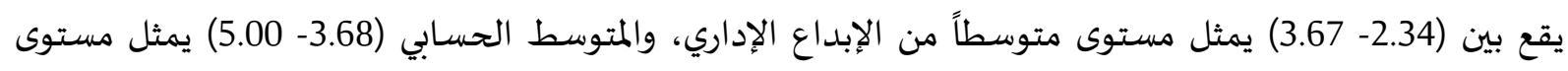
مرتفعاً من الإبداع الإداري.

\begin{tabular}{|c|c|}
\hline قليلة & من 1.00- 2.33 \\
\hline متوسطة & من 2.34- 3.67 \\
\hline كبيرة & $5.00-3.68$ \\
\hline
\end{tabular}

المعالجة الإحصيائية

1- تم استخدام برنامج التحليل الإحصائي (SPSS) من خلال الأساليب الإحصائية الآتية:

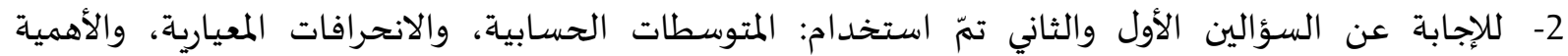
النسبية، والتكرارات. 3- ولإجابة عن السؤال الثالث فقد تم استخدام اختبار تحليل التباين المتعدد (Multiple ANCOVA). 4- - 1 - عرض النتائج ومناقشتها.

إجابة السؤال الأول: "ما درجة ممارسة الإدارة المدرسية لدورها في تنمية الإبداع في المدارس الحكومية في مديرية لواء الجامعة من وجهة نظر مديريها؟ الاول ما درجة ممارسة الإدأ للإجابة عن هذا السؤال تم استخراج المتوسطات الحسابية والانحرافات المعيارية لدرجة ممارية مارسة الإدارة

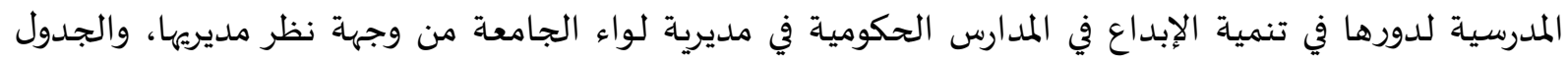
(4) أدناه يوضح ذلك.

جدول (4) المتوسطات الحسابية والانحرافات المعيارية لإجابات العينة حول درجة ممارسة الإدارة المدرسية لدورها في تنمية الإبداع في المدارس الحكومية في مديرية لواء الجامعة مرتبة تنازلياً حسب المتوسطات المات الحسات الحسابية

\begin{tabular}{|c|c|c|c|c|c|}
\hline 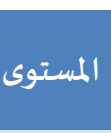 & 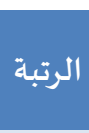 & المعياري - المراف & المستوسط & 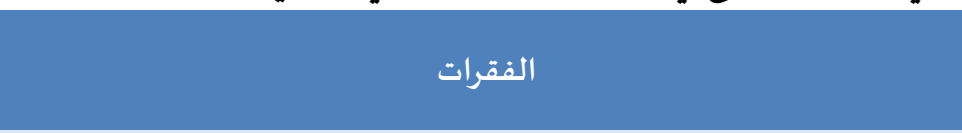 & $\hat{\imath}$ \\
\hline \multirow{5}{*}{ 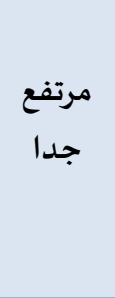 } & 1 & .64 & 4.33 & يمتلك مدير المدرسة روح المبادرة لتنفيذ الأعمال بشكل جيد & 26 \\
\hline & 2 & .64 & 4.31 & تقيم إدارة الممدرسة علاقات احترام مع العاملين مما يساعد في تنمية الإبداع & 25 \\
\hline & 3 & .73 & 4.25 & تحفّز الإدارة المعلمين مادياً ومعنويا مما ينمي الإبداع بشكل جيد للدراسة & 19 \\
\hline & 4 & .72 & 4.24 & تبنّي المرونة في التعامل مع المعلمين والطلاب لزيادة الإبداع بشكل أفضل & 10 \\
\hline & 5 & .66 & 4.22 & يزبد الذكاء العاطفي لمدير المدرسة من تنمية الإبداع في المدرسة & 9 \\
\hline \multirow[t]{4}{*}{ 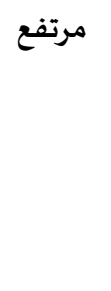 } & 6 & .70 & 4.20 & يساعد منح المعلمين بعض الصلاحيات في تنمية الإبداع في المدرسة & 15 \\
\hline & 7 & .74 & 4.16 & وجود نظام حوافز للطلبة يساهم في تنمية الإبداع & 28 \\
\hline & 8 & .80 & 4.15 & تؤكد الإدارة المدرسية على ربط المنهاج الدراسي بتطبيقاته العملية بأنشطة تثير & 18 \\
\hline & 9 & .69 & 4.07 & تمتلك الإدارة القدرة على التكيف مع طبيعة المواقف المختلفة في العمل & 13 \\
\hline
\end{tabular}




\begin{tabular}{|c|c|c|c|c|c|}
\hline المستوى & 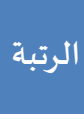 & الاندراف & المتوســ & 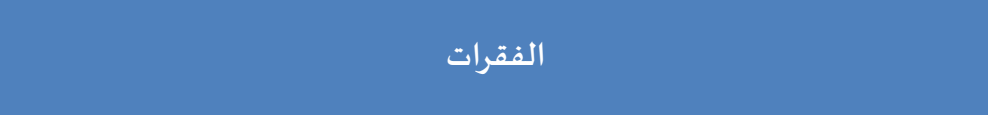 & $\hat{\imath}$ \\
\hline \multirow{18}{*}{ 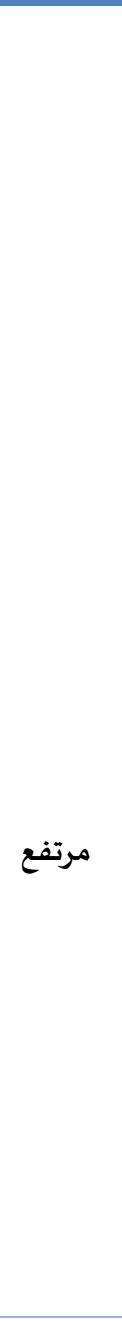 } & 10 & .69 & 4.07 & تسمح الإدارة المدرسية بالحوار مع المعلمين ومناقشتهم في العمل التربوي & 23 \\
\hline & 11 & .74 & 4.07 & تغرس الإدارة مبادئ الإبداع والابتكاروالتجديد في نفوس المعلمين والطلبة & 24 \\
\hline & 13 & .62 & 4.05 & لدى الإدارة المدرسية رؤية دقيقة لاكتشـاف المشكلات التي يعاني منها الاخرون في & 27 \\
\hline & 12 & .76 & 4.05 & توفر الإدارة مناخًا تعليميًا تعلميًا اجتماعيًا يشجع على تنمية القدرات الابداعية & 16 \\
\hline & 14 & .90 & 4.04 & تتبنى الأفكار الإبداعية الصيادرة من قبل المعلمين & 6 \\
\hline & 15 & .76 & 4.02 & تتخذ الإدارة المدرسية القراروفقا لأسس علمية & 14 \\
\hline & 16 & .72 & 4.00 & تنجز الأعمال بأسلوب متطور وجديد & 5 \\
\hline & 17 & .84 & 4.00 & 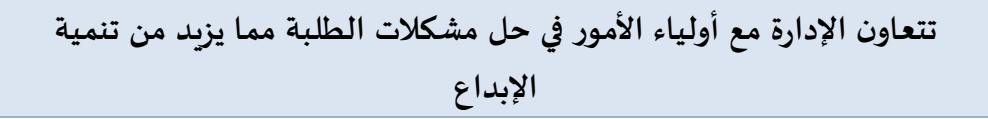 & 11 \\
\hline & 19 & .78 & 3.98 & تساعد الأنشطة المدرسية المساندة للمناهج على اكتشاف الموهوبين والمبدعين في & 12 \\
\hline & 18 & .85 & 3.98 & تبحث باستمرار عن الأفكار الجديدة والمبدعة وتتبناها لتطوير العمل & 4 \\
\hline & 20 & .85 & 3.98 & تشـارك الإدارة المدرسية المعلمين المبدعين في وضع الخطط واتخاذ القرارات & 20 \\
\hline & 21 & .71 & 3.95 & تحرص على معرفة أوجه القصور أو الضعف في أعمالها بغرض التخلص منها & 17 \\
\hline & 22 & .77 & 3.93 & تلبي الإدارة المدرسية حاجات المتعلمين & 1 \\
\hline & 23 & .89 & 3.85 & تتعاون الإدارة مع المشرف التربوي لتنمية الإبداع في العملية التعليمية & 7 \\
\hline & 25 & .71 & 3.84 & تخصص الإدارة ميزانية للأنشطة اللاصفية التي تسـاعد في تنمية الإبداع & 8 \\
\hline & 24 & .79 & 3.84 & تشجع الإدارة المدرسية على إثراء المناهج بأنشطة إبداعية & 3 \\
\hline & 26 & .98 & 3.82 & تسهم المناهج التعليمية في تنمية الإبداع لدى الطلبة & 22 \\
\hline & 27 & .87 & 3.73 & تستطلع آراء أولياء الأمور حول تحصيل أبنائهم مما يزيد من فرص تنمية الإبداع & 21 \\
\hline متوسط & 28 & .85 & 3.64 & تعقد الإدارة المدرسية دورات لتأهيل المعلمين بهدف تنمية الإبداع لدى طلبتهم & 2 \\
\hline 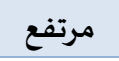 & & .53 & 4.03 & المتوسط الكلي لدور الإدارة & \\
\hline
\end{tabular}

يبين الجدول (4) ان المتوسطات الحسابية قد تراوحت ما بين (3.64-4.33)، حيث جاءت الفقرة رقم (26)

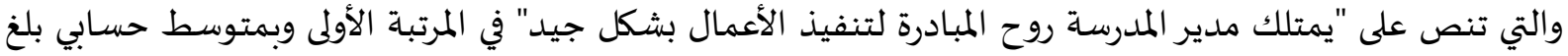
(4.33)، وجاءت الفقرة رقم (25) والتي تنص على "تقيم إدارة المدرسة علاقات احترام مع العاملين مما يساعد في تنمية الإبداع" في المرتبة الثانية وبمتوسط حسابي بلغ (4.31)، بينما جاءت الفقرة رقم (2) ونصها تعقد الإدارة المدرسية دورات لتأهيل المعلمين بهدف تنمية الإبداع لدى طلبتهم بالمرتبة الأخيرة وبمتوسط حسابي بلغ (3.64). وبلغ المتوسط الحسابي لدور الإدارة ككل (4.03). وبذلك تكون نتائج الدراسة اتفقت مع دراسة (عثمان وعبد الرحمن،

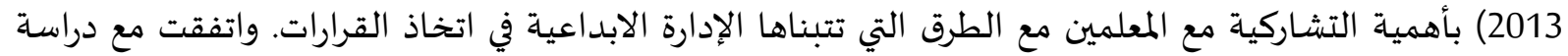

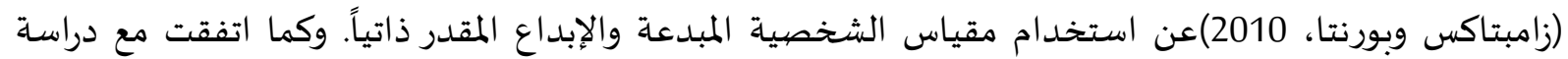

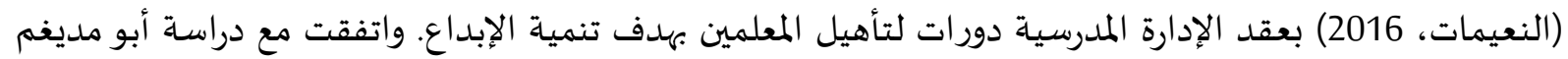
وحجازي وطشطوش (2018) بأن درجة ممارسة الإبداع جاءت بدرجة كبيرة، ودراسة سويطي (2015) أيضا جاء دورة الإداء

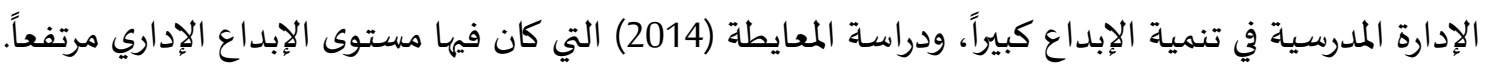


إجابة السؤال الثاني: "ما المُعيقات التي تواجه المديرفي تنمية الإبداع عند الطلبة؟

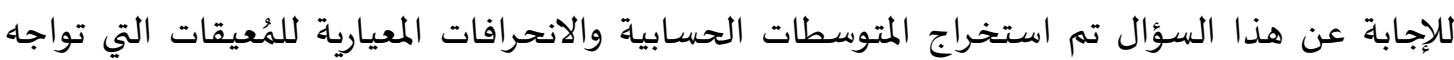

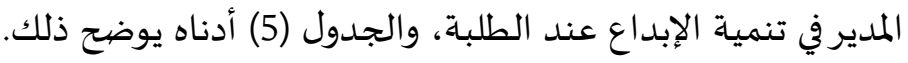
جدول (5) المتوسطات الحسابية والانحرافات المعيارية للمُعيقات التي تواجه المدير في تنمية الإبداع عند المنداع الطلبة مرتبة تنازلياً حسب المتوسطات الحسابية

\begin{tabular}{|c|c|c|c|c|c|}
\hline 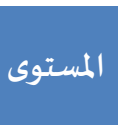 & 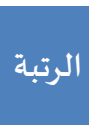 & 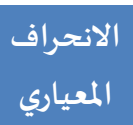 & المتوسط المسابي & 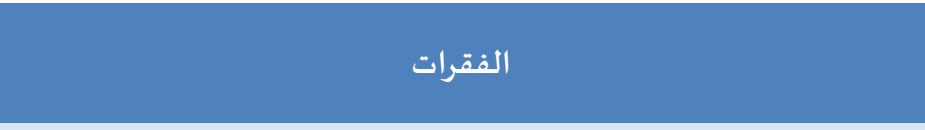 & $\hat{\imath}$ \\
\hline 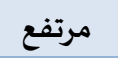 & 1 & .86 & 4.07 & عدم منح الصلاحيات الكافية للمديرين يعيق تنمية الإبداع & 36 \\
\hline 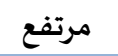 & 2 & .93 & 3.81 & عدم توفر المرافق اللازمة لتنفيذ الأنشطة يشكل عائقا أمام تنمية الإبداع & 31 \\
\hline 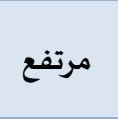 & 3 & .92 & 3.78 & كثرة الأعباء الإدارية والمكتبية لا توفر للمدير الوقت الكافي للتخطيط وتنفيذ & 32 \\
\hline 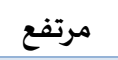 & 4 & .94 & 3.76 & عدم وجود معلمين متخصصين بالنشاطات الإبداعية & 34 \\
\hline 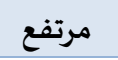 & 6 & .96 & 3.74 & تعاني المدارس من عدم توفر إمكانات مادية تساعد على تنمية الإبداع فيها & 30 \\
\hline متوسط & 7 & .92 & 3.29 & قلة الدعم المادي يُشكل عائقا في تنمية الإبداع & 33 \\
\hline متوسط & 8 & 1.0 & 3.27 & البيئة المدرسية تعيق توفير مناخ للإبداع في المدرسة & 29 \\
\hline مرتفع & & .68 & 3.68 & المتوسط الكلي للمعيقات & \\
\hline
\end{tabular}

يبين الجدول (5) ان المتوسطات الحسابية قد تراوحت ما بين (3.27-4.07)، حيث جاءت الفقرة رقم (36)

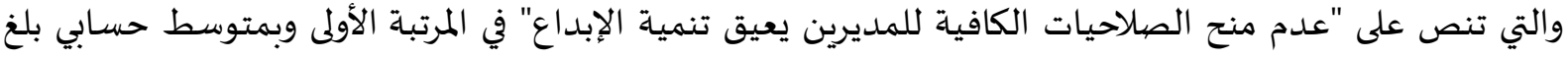

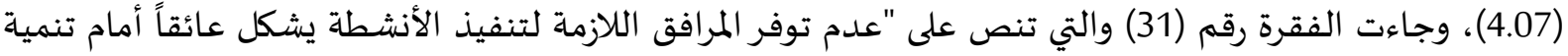

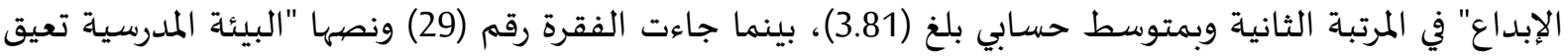
توفير مناخ للإبداع في المدرسة" بالمرتبة الأخيرة وبمتوسط حسابي بلغ (3.27). وبلغ المتوسط الحسابي للمعيقات ككل

وبذلك تكون اتفقت مع دراسة العنزي (2020) بأن أهم معيقات التفكير الإبداعي تتعلق بالبيئة المدرسياة، ودراسة حفيظي (2019) بأنه لن يتم التعليم الإبداعي في ظروف صفية لا يتوفر فهها التدريس الإبداعي، وللمدرسة دور فاعل في ذلك. كما اتفقت مع دراسـة سويطي (2015) بأن عدم توفر بيئة مدرسية تحتوي على على المرافق اللازمة

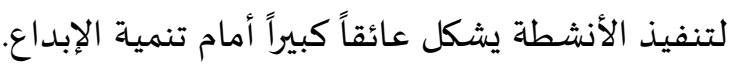
وعليه تؤكد الباحثة على أهمية منح المديرين بعض الصلاحيات فيما يتعلق باتخاذ القرار، وتنفيذ الأنشطة

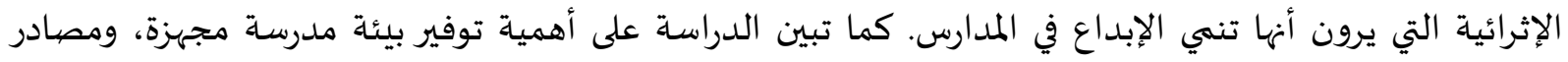

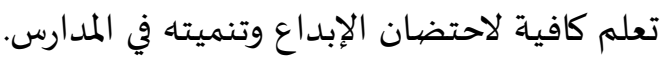

إجابة السؤال الثالث: هل توجد فروق دالّة إحصيائياً عند مستوى الدلالة (X2 0.05) في تقدير المديرين

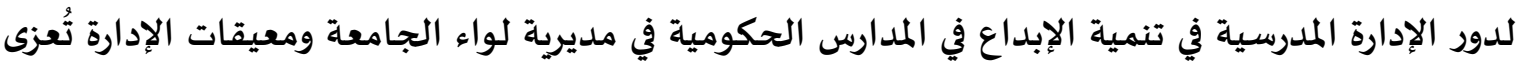

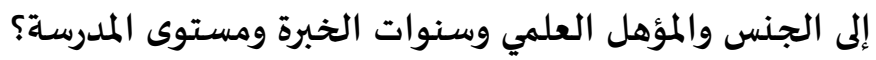
لالإجابة عن هذا السؤال تم استخراج المتوسطات الحسابية والانحرافات المعيارية لدور الإدارة المدرسية في تنمية الإبداع في المدارس الحكومية في مديرية لواء الجامعة ومعيقاتها حسب متغيرات الجنس والمؤهل العلمي وسنوات الخبرة ومستوى المدرسة والجدول (6) أدناه يبين ذلك. 
جدول رقم (6) المتوسطات الحسابية والانحرافات المعيارية لدور الإدارة المدرسية في تنمية الإبداع في المدارس الحكومية في مديرية لواء الجامعة حسب متغيرات الجنس والمؤهل العلمي وسنوات الخبرة ومستوى المدرسة

\begin{tabular}{|c|c|c|c|c|}
\hline الانحراف المعياري & المتوسط الحسابي & 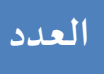 & الفئات & المتغير \\
\hline .516 & 3.84 & 21 & ذكر & \multirow{2}{*}{ الجنس } \\
\hline .518 & 4.14 & 34 & أنثى & \\
\hline .517 & 4.03 & 35 & دبلوم عال & \multirow{2}{*}{ المؤهل العلمي } \\
\hline .573 & 4.02 & 20 & دراسات عليا & \\
\hline .459 & 4.02 & 22 & أقل من 5 سنوات & \multirow{3}{*}{ سنوات الخبرة في } \\
\hline .581 & 4.01 & 13 & من 5- 10 سنوات & \\
\hline .600 & 4.05 & 20 & أكثر من 10 سنوات & \\
\hline .504 & 4.10 & 30 & أسـاسي & \multirow{2}{*}{ مستوى المدرسـة } \\
\hline .563 & 3.94 & 25 & ثانوي & \\
\hline
\end{tabular}

يبين الجدول (6) تبايناً ظاهرياً في المتوسطات الحسابية والانحرافات المعيارية لدور الإدارة المدرسية في تنمية

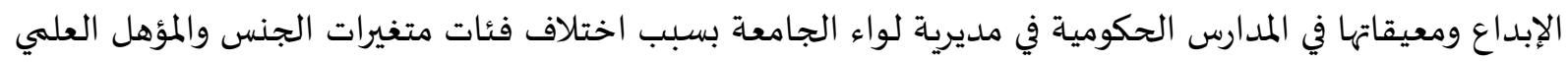

وسنوات الخبرة ومستوى المدرسة.

ولبيان دلالة الفروق الإحصائية بين المتوسطات الحسابية تم استخدام تحليل التباين الرباعي جدول (7).

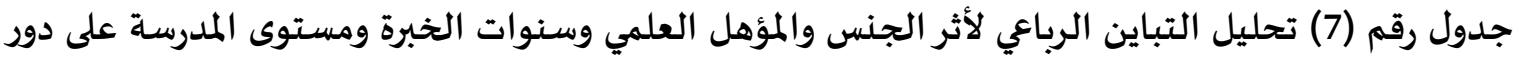
الإدارة المدرسية في تنمية الإبداع في المدارس الحكومية في مديرية لواء الجامعة لمونة

\begin{tabular}{|c|c|c|c|c|c|}
\hline الإحصدائية الدلة & قيمة ف & متوسط & درجات الحرية & المربعات & مصيدر التباين \\
\hline .042 & 4.341 & 1.216 & 1 & 1.216 & الجنس \\
\hline .740 & .111 & .031 & 1 & .031 & المؤهل العلمي \\
\hline .827 & .191 & .053 & 2 & .107 & سنوات الخبرة في العمل \\
\hline \multirow[t]{3}{*}{.275} & 1.218 & .341 & 1 & .341 & مستوى المدرسـة \\
\hline & & .280 & 49 & 13.726 & الخطأ \\
\hline & & & 54 & 15.332 & الكلي \\
\hline
\end{tabular}

يتبين من الجدول (7) الآتي:

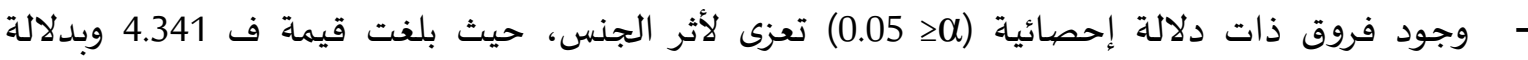

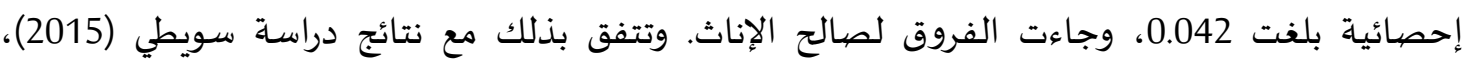
وتختلف مع نتائج دراسة النعيمات (2016) ودراسة السودي (2016) والحجوج (2018). وتعزو الباحثة هذه واءت

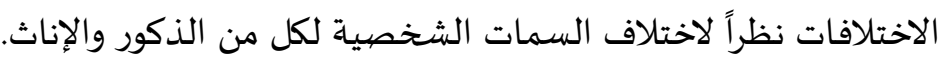

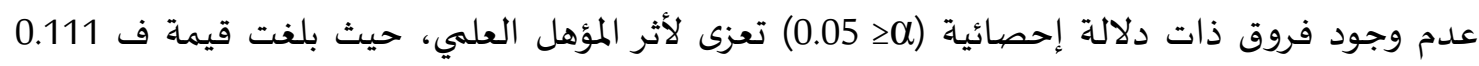

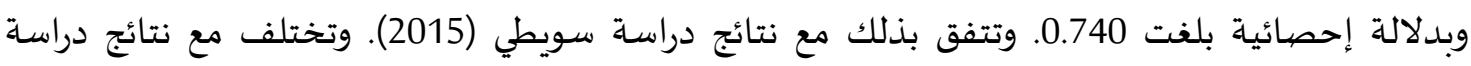


السودي (2016)، ودراسة النعيمات (2016)، والمعايطة (2014). وتعزو الباحثة ذلك لاتفاق المديرين من

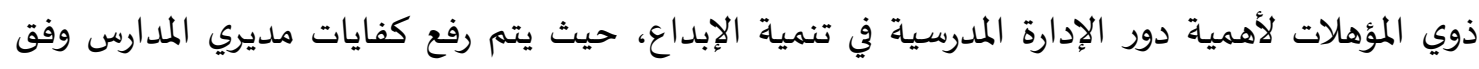
برامج تدريب وتأهيل معتمدة من وزارة التربية والتعليم.

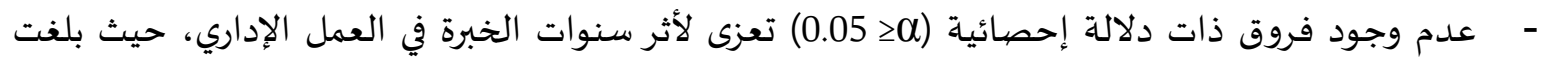

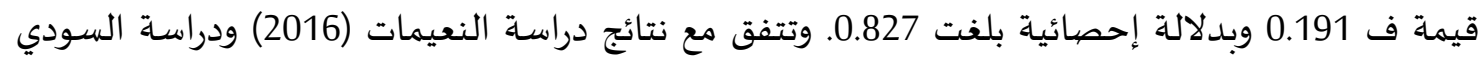
(2016). والمعايطة (2014)، ودراسة عبابنة والشقران (2013).

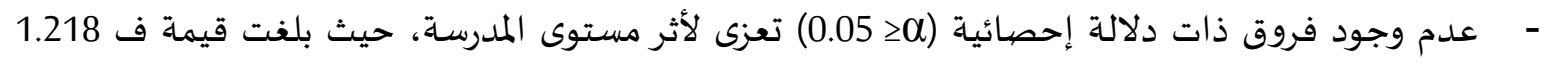
وبدلالة إحصائية بلغت 0.275. التوصيات والمقترحات

في ضوء النتائج التي تمّ التوصل إليها توصي الباحثة وتقترح بما يأتي:

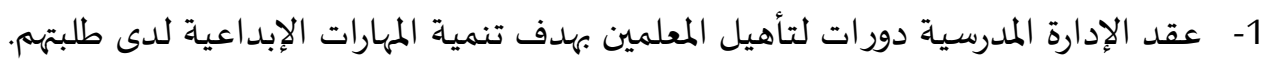

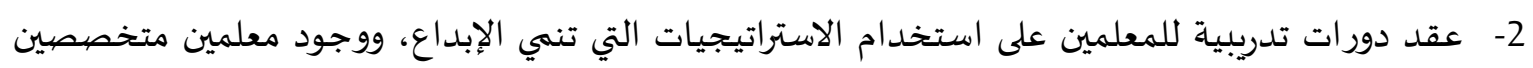
بالنشاطات الإبداعية. 3- إعداد برامج تدريبية يلتحق بها مديرو المدارس الحكومية لتنمية المهارات الإبداعية لديهم ومواكبة التطور

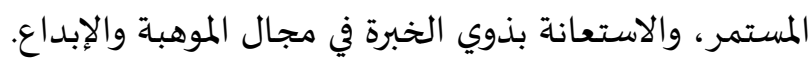

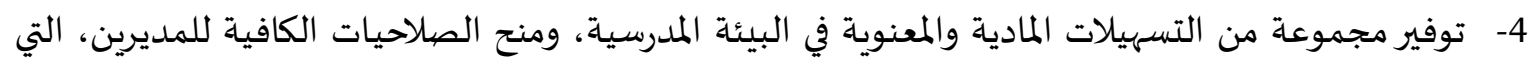
من شأها تعزيز النمو الإبداعي لدى المعلمين والمتعلمين.

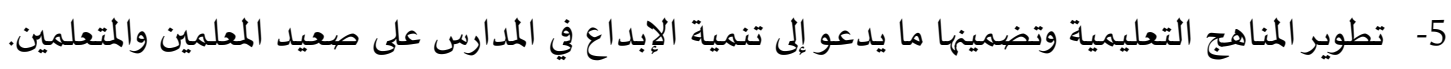
6- توفير المرافق اللازمة لتنفيذ الأنشطة الإبداعية.

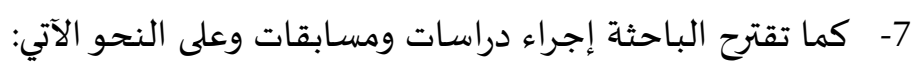
1.

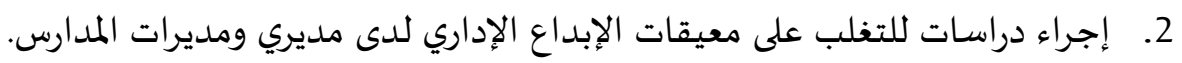
3. إجراء مسابقات ومبادرات في المدارس تشجع وتحفز الإبداع وتنمياء.

\section{قائمة المراجع}

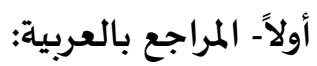

- ابن منظور، أبو الفضل جمال الدين الافريقي المصري (2004). لسان العرب، ط 3، بيروت، دار صادر للطباعة والنشر، ص 279.

- - أبو النصر، مدحت (2004). تنمية القدرات الابتكارية لدى الفرد والمنظمة، القاهرة، مجموعة النيل العربية.

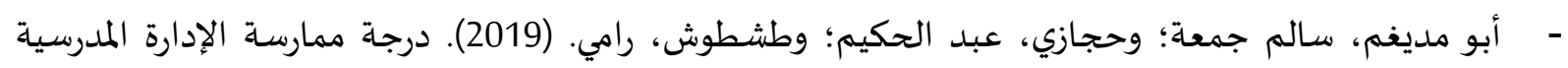

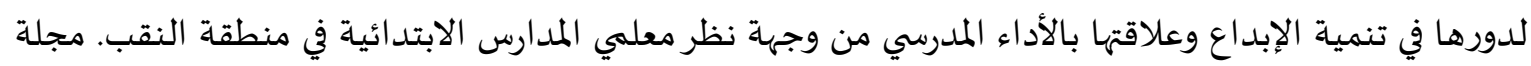

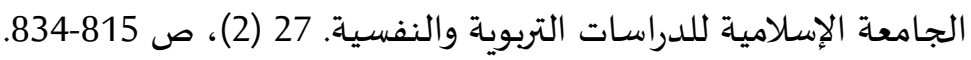


أبو جامع، إبراهيم؛ والطويل، عبد الرحمن (2011). الثقافة التنظيمية والإبداع الإداري في وزارة التربية والتعليم

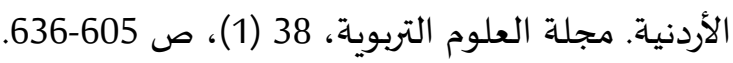
أحمد، ابراهيم (2003). الإدارة المدرسية في مطلع القرن الحادي والعشرين، دار الفكر العربي ط1، القاهرة، - البارقي، محمد (2012). درجة ممارسة مدير المدرسة الثانوية لمهامه مشرفاً مقيماً في ضوء تحديات العولمة من وجها نظر مديري ومعلمي المرحلة الثانوية في جدة، المؤسسة العربية للاستشارات العلمية وتنمية الموارد

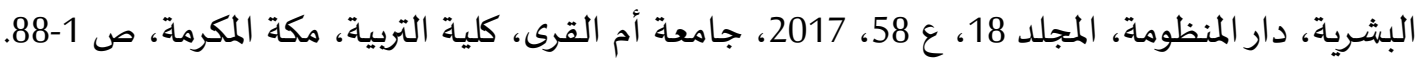

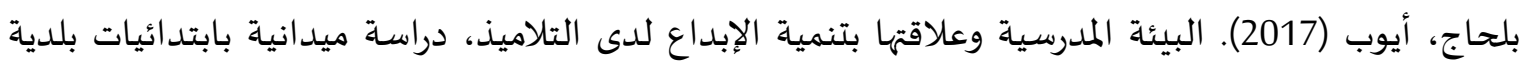

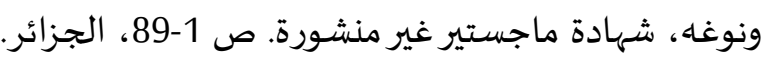

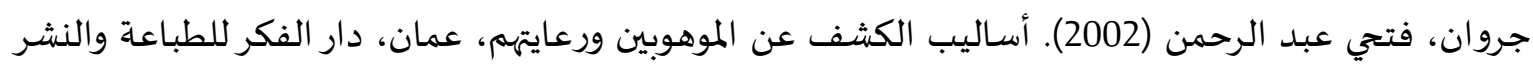
والتوزيع، الاردن.

جروان، فتحي عبد الرحمن (2009). الإبداع، مفهومه، معاييره، نظرياته، قياسـ، تدرببه، مراحل العملية

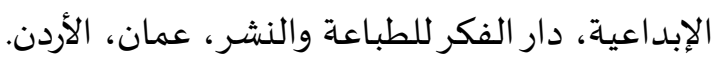
جروان، فتحي عبد الرحمن (2012). الموهبة والتفوق والإبداع، دار الفكر ناشرون وموزعون، ط4ان، عمان، الإدنان الأردن. الحجوج، أكرم محمد، وأبو علي، عبد القادر خالد (2018). واقع الإبداع الإداري لدى مديري المدارس الحكومية

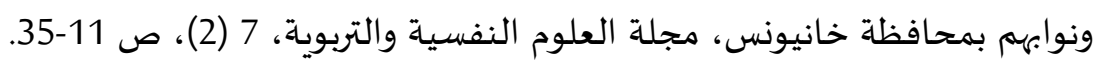

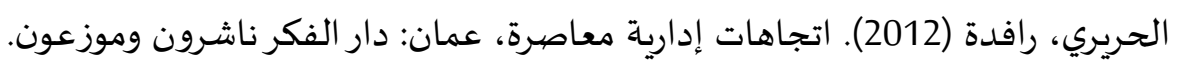

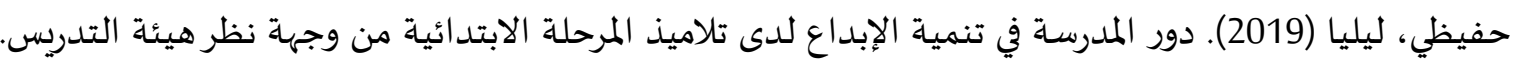

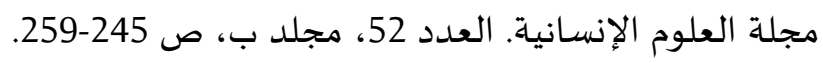

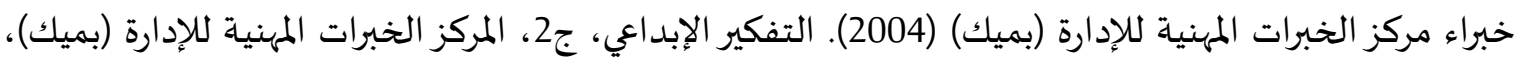

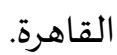
خبراء مركز الخبرات المهنية للإدارة (بميك) (2006). المناهج التدريبية المتكاملة. مركز الخبرات المهنبة للإدارة (بميك)، القاهرة. الدليمي، طارق عبد أحمد (2013). الاتجاهات الحديثة في الإدارة التربوية والمدرسية، مركز ديبونو لتعليم التفكير، عمان، الاردن. التمبن

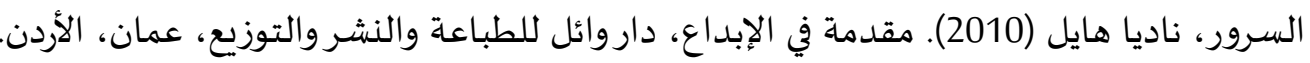

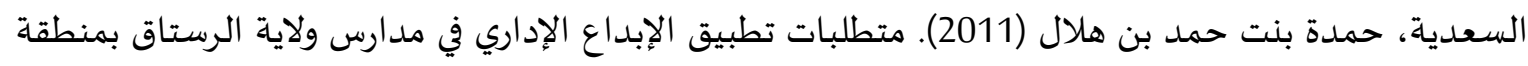

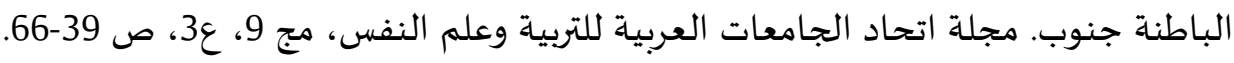

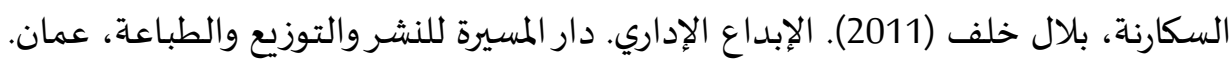

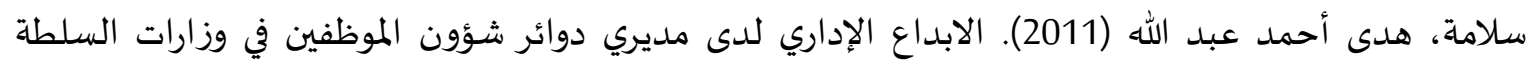
الوطنية الفلسطينية، رسالة ماجستير غير منشورة، جامعاة القدس المفتوحة- رام الله، فلسطين.

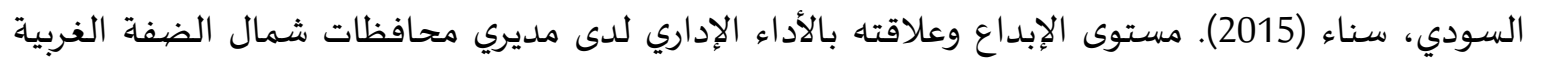

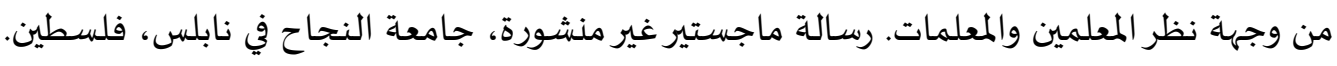


سويطي، عبد الناصر (2015). دور الإدارة المدرسية في تنمية الإبداع في المدارس الحكومية في محافظتي الخليل

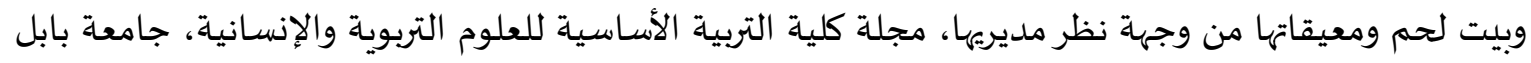
ص (50-27). شقور، محمد حسن. (2002). الإدارة المدرسية في عصر العولمة، ط3، دار المسيرة للنشر والتوزيع والطباعة،

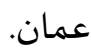
الشمري، فهيد عايض (2002). المدخل الإبداعي لإدارة الأزمات والكوارث. الرياض: شركة مطابع نجد التجارية.

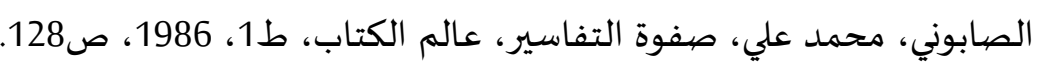

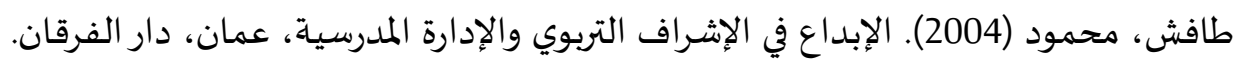

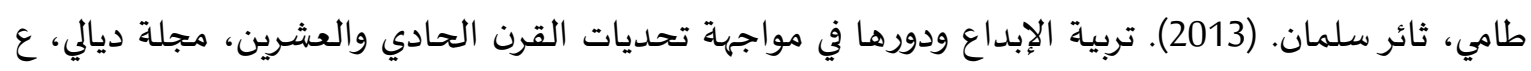

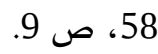
الطيب، محمد العلوي (1982). التربية والإدارة في المدارس الأساسية، دار البحث للطباعة ط1، ج1، قسطنطينة، ص -62-139. - الطيطي، مسلم يوسف؛ وأبداح، رائد؛ وجرادات، مجي الدين (2016). دور مديري المدارس الأساسية في تنمية

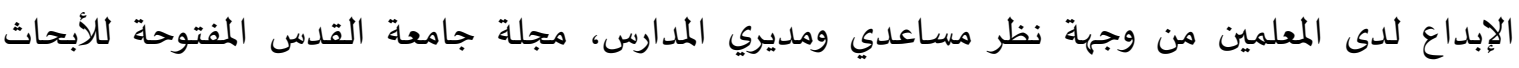

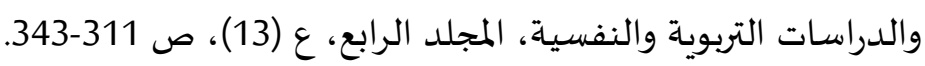
عبابنة، رامي؛ والشقران، رامي (2013). درجة ممارسة الإبداع الإداري لدى القادة التربويين في مديريات التربية التربية

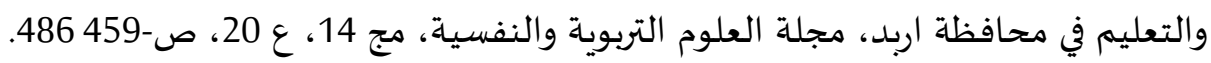

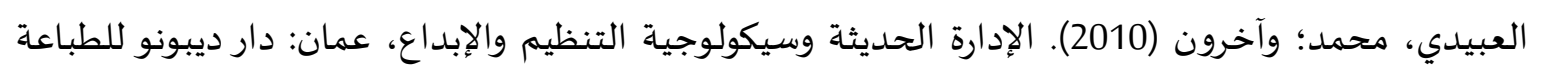
والنشر والتوزيع. عطوي، جودت عزت (2015). الإدارة المدرسية الحديثة مفاهيمها النظرية وتطبيقاتها العملية، دار الثقافة للنشر

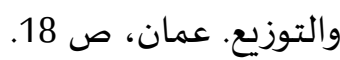
العنزي، سلامة عجاج (2020). معيقات تنمية التفكير الإبداعي لدى تلاميذ المرحلة الابتدائية من وجهة نظر

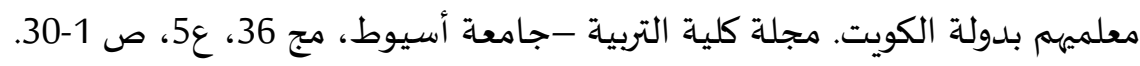
القمش، مصطفى نوري. (2011). مقدمة في الموهبة والتفوق العقلي. ط1، دار المسيرة للنشر والتوزيع والطباعة.

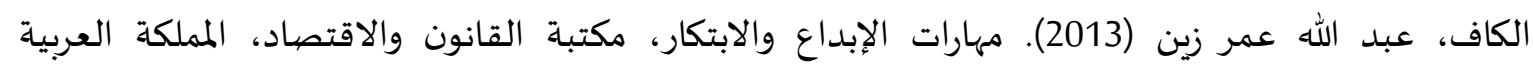
السعودية، ص 125-130. الكناني، ممدوح عبد المنعم (2015). سيكولوجية الابداع وأساليب تنميته، دار المسيرة للنشر والتوزيع والطباعة، الطيعة الثانية، عمان، الاردن.

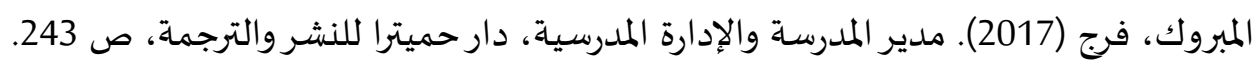
المجدوبي، كريمة بشير (2020). التفكير الإبداعي ومعوقاته في مرحلة التعليم الأساسي من وجها المادية نظر المعلمين

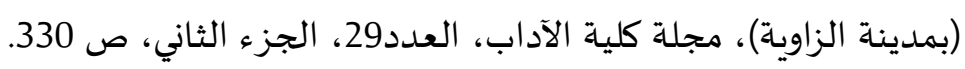

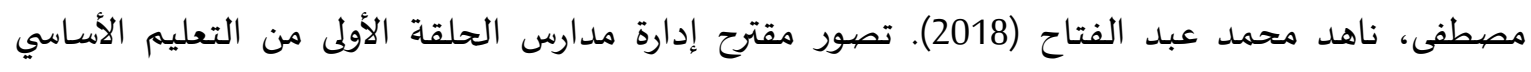

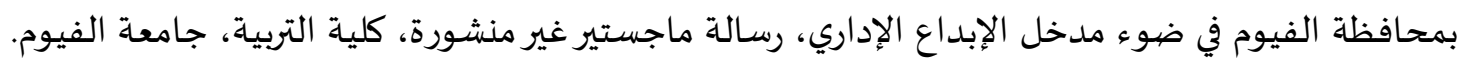

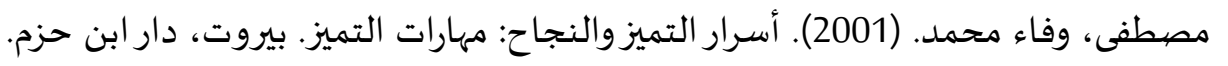


- المعايطة، خليل عبد الرحمن؛ والبواليز، محمد عبد السلام. (2000). الموهبة والتفوق. ط1، دار الفكر للطباعة والنشر والتوزيع، الأردن.

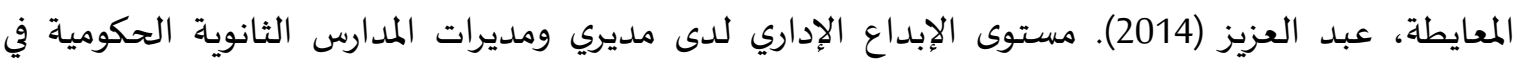

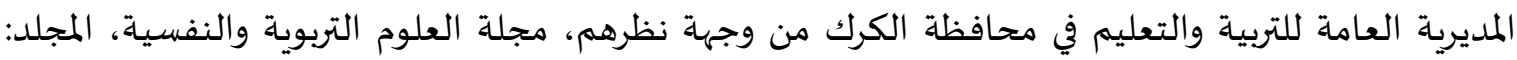
15، العدد: 4. ص: 541- 580.

نصر، عزة (2008). الإبداع الإداري التطوير الذاتي للمدرسة الثانوية، رؤية استراتيجية، المركز القومي للبحوث التربوية.

النعيمات، محمود موسى (2016). دور القيادة المدرسية في تنمية الإبداع لدى معلمي مدارس المرحلة الثانوية في

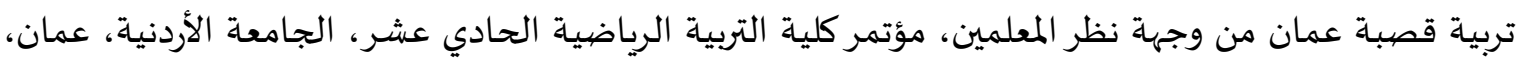

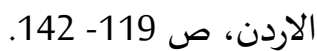
- يونس، موسى. (2000). التفوق الإداري، الرياض، بيت الأفكار الدولية للنشروالتوزيع.

\section{ثانيا- المراجع بالإنجليزية: إ}

- Botha, R., J. (2013). The Need for Creative Leadership in South Africa Schools African Students, 72 (2) p, 307-320.

- Bush. T, (2008). Theories of Educational Leadership and Management, $3^{\text {rd }}$ ed., London, Sage Publications, Ltd.

- Othman, Azzam \& AbdRahman, Honidon (2013). Innovative Leadership: Learning from Change Management among Malaysian Secondary School Principle. Word Applied Sciences Journal2013. vol. 23, Issue 2- p167-177.

- Sherelle, Lou, and Catherine, Sumere (2017). Conflicts and Resolutions of School Administrators: Basis for Innovative Administrative Program, Asia Pacific Journal Contemporary Education and Technology (APJCECT), vol 3, Issue 1, p 247-260.

- Zametakis, L. Bouranta, N. \&moustakis, V. (2010). On the Relationship between individual Creativity and the time management. Thinking skills and creativity 5 (1), p23-32. 